\title{
Vulnerability assessment of mangroves to climate change and sea-level rise impacts
}

\author{
Joanna C. Ellison
}

Received: 8 October 2014/Accepted: 1 December 2014/Published online: 31 December 2014

(C) The Author(s) 2014. This article is published with open access at Springerlink.com

\begin{abstract}
Climate change, particularly its associated sea level rise, is major threat to mangrove coastal areas, and it is essential to develop ways to reduce vulnerability through strategic management planning. Vulnerability has three dimensions of exposure to stresses, associated sensitivity, and related adaptive capacity, and ways to measure components of each were trialled at sites in Africa and the South Pacific to develop an analysis procedure based on ranking. The approaches of the ranking system for vulnerability assessment of mangrove systems integrate biotic and abiotic factors along with human management components, using validated methods previously developed for other research questions. These include determining mangrove forest health, adjacent ecosystem resilience, the extent and effects of human impacts, and the environmental conditions of different mangrove settings. Results of the vulnerability assessment ranking using up to 20 measurements found all sites to have some components of vulnerability. Douala Estuary, Cameroon showed the highest vulnerability, owing to low tidal range, impacts from nonclimate stressors, and evidence of moderate seaward edge retreat. Tikina Wai, Fiji showed inherent vulnerability owing to location on a subsiding coastline with a low tidal range, but this was offset by strong
\end{abstract}

J. C. Ellison ( $\square)$

School of Land and Food, University of Tasmania, Locked Bag 1370, Launceston, TAS 7250, Australia

e-mail: Joanna.Ellison@utas.edu.au local community management capacity. Rufiji Delta, Tanzania showed inherent resilience owing to location on an uplifting coastline with a macrotidal range, but showed vulnerability from human impacts and lower local community management capacity. The most critical components to the vulnerability assessment were found to be exposure components of relative sea level trends and sediment supply, and sensitivity components of forest health, recent spatial changes and net accretion rates. The results provide a baseline against which to establish long-term ongoing monitoring, allowing continued assessment of the complex dynamics of climate change impacts, and providing an information base for strategic management decisions.

Keywords Mangroves - Sea level rise · Vulnerability $\cdot$ Ranking $\cdot$ Exposure $\cdot$ Sensitivity Adaptive capacity

\section{Introduction}

Despite the mangrove values of coastal protection, fish and wildlife habitats, sediment and pollution filtering and carbon sequestration (Mumby et al. 2004; Spalding et al. 2010; Bouillon 2011) mangrove areas have rapidly reduced in recent decades (Giri et al. 2011a) and many remaining habitats suffer from unsustainable use (Spalding et al. 2010). Climate change has recently started to compound the effects of direct 
human pressures (Wong et al. 2014). Degradation and loss of these coastal buffering systems due to climate change and direct human impacts negates the coastal protection they provide during extreme events and increases their vulnerability, with significant environmental, economic and social consequences for coastal people.

\section{Vulnerability}

Vulnerability is an inclusive concept for analysing coupled social-ecological response to environmental change (Kelly and Adger 2000; Turner et al. 2003; Adger et al. 2007; Füssel 2007; Polsky et al. 2007; Mertz et al. 2009), defined as the propensity or predisposition to be adversely affected (Oppenheimer et al. 2014). Climate change vulnerability assessments of ecosystems (Zhao et al. 2007; Johnson and Marshall 2007; Nitschke and Innes 2008; Glick and Stein 2010; Bell et al. 2011) have followed an outcome/endpoint interpretation of vulnerability (Remling and Persson 2014), where the solutions are in reducing exposure through climate change mitigation, and technical and sectoral adaptation to limit negative outcomes.

Vulnerability has been conceptualised to have three dimensions: exposure to stresses, associated sensitivity, and related adaptive capacity (Adger 2006; Polsky et al. 2007; Fig. 1). Vulnerability assessment incorporates a significant range of parameters in building quantitative and qualitative understanding of the processes and outcomes of vulnerability (Adger 2006), and its application to intertidal mangrove ecosystems has the capacity to improve climate change adaptation planning.

Vulnerability is not, however, a quantitative metric (Füssel 2007), but rather is a relative, non-measurable dimensionless property (Stigter et al. 2006). The three dimensions of vulnerability have been categorised into components, or the abstract features upon which to evaluate exposure, sensitivity and adaptive capacity

Fig. 1 Vulnerability as a combined function of exposure, sensitivity and adaptive capacity (adapted from Polsky et al. 2007)

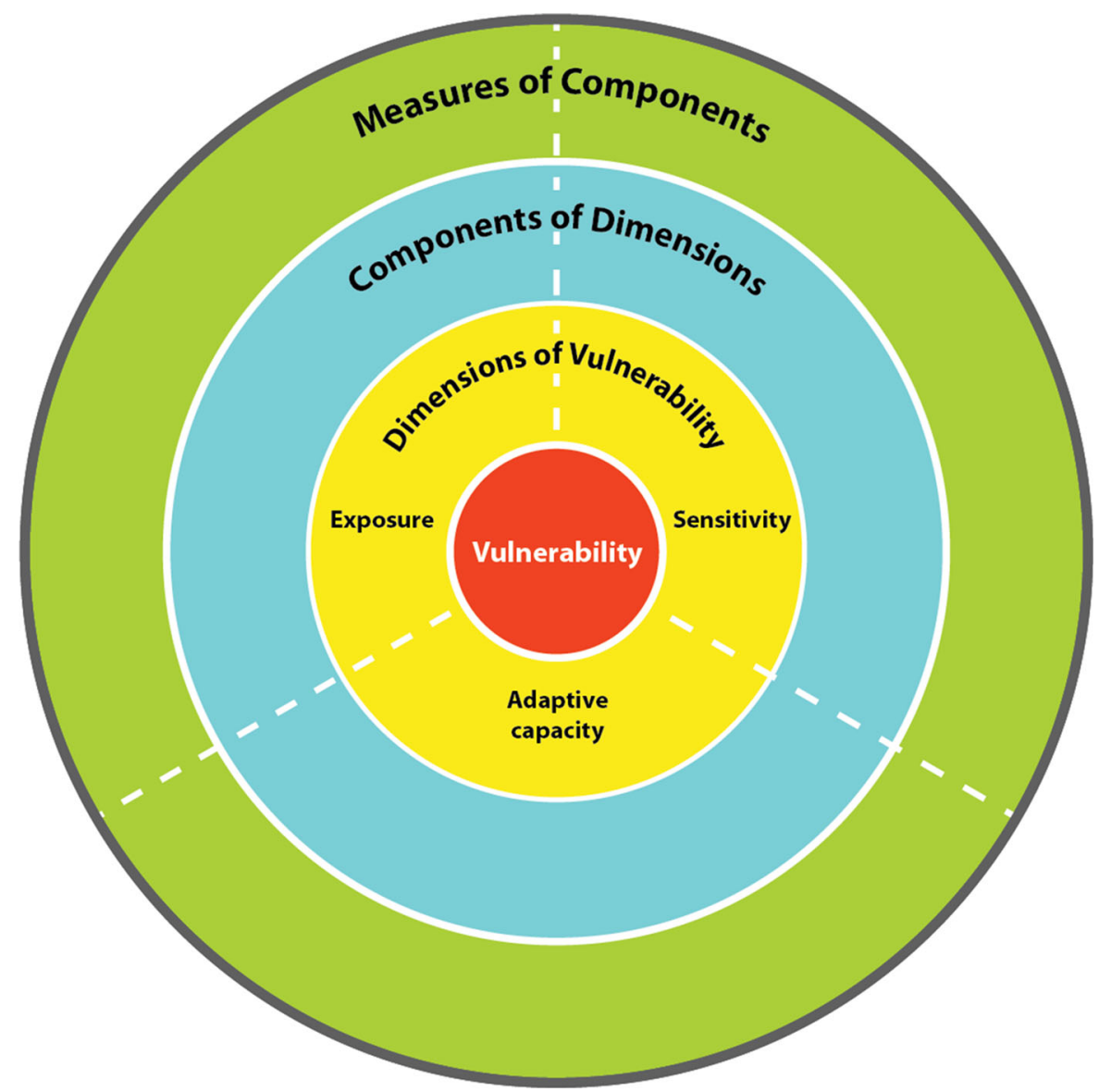


(Polsky et al. 2007). These features can each be evaluated using a number of measurements (Fig. 1), which are the observable characteristics of each of the component features (Polsky et al. 2007). The following sections review the exposure, sensitivity and adaptive capacity components for mangroves, to identify effective measurements.

\section{Exposure}

Exposure refers to extrinsic stresses such as the magnitude and rate of change that a species or system is likely to experience (Adger 2006; Füssel and Klein 2006). Table 1 reviews the key climate change exposure components affecting mangroves. Temperature warming and the direct effects of increased $\mathrm{CO}_{2}$ have been found to be mostly beneficial to mangroves, increasing mangrove productivity and latitudinal range (Field 1995, Alongi 2008, Waycott et al. 2011). Rainfall changes bring greater potential sensitivity, particularly reduced freshwater availability, which decreases mangrove productivity and biodiversity (Field 1995, Alongi 2008; Waycott et al. 2011). However, the effects of relative sea level rise have been found to be the primary exposure of concern, with detrimental effects on mangroves (Table 1).

Sea level rise projections have recently increased relative to those considered by sources in Table 1 , so increasing the potential exposure. The Fourth Intergovernmental Panel on Climate Change (IPCC) assessment predicted a global sea level rise of $0.18-0.59 \mathrm{~m}$ by the end of the $21 \mathrm{st}$ century (Meehl et al. 2007). The Fifth IPCC assessment projects a global rise in mean sea level for 2081-2100 relative to 1986-2005 of 0.2-0.98 m, depending on different emissions scenarios. The highest scenario would give a rate at the end of the 21 st century of $8-16 \mathrm{~mm} \mathrm{a}^{-1}$ (Church et al. 2013), increased from a previous maximum of $9.7 \mathrm{~mm} \mathrm{a}^{-1}$ (Meehl et al. 2007). Since the mid-19th century sea level rise increased relative to the previous two millennia, with global mean sea

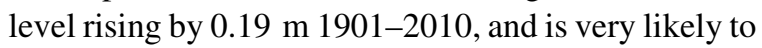
have accelerated after 1993 (Church et al. 2013). Coastlines that are subsiding (Syvitski et al. 2009) would have greater exposure.

Other environmental conditions as well as climate change contribute to the susceptibility of a system to harm (Stern et al. 2013). While sea-level rise and reduced precipitation are exposure components directly related to climate change, mangroves have exposure factors independent of climate change that may cause increased sensitivity as stress increases. These are characterised by different mangrove geomorphic settings and include tidal range, fluvial sediment supply, variability in wave energy, and lead to different specific vulnerabilities (Table 2). Riverdominated settings are more vulnerable to changes in catchment runoff and therefore freshwater availability and sediment supply, while low island settings may be more vulnerable to relative sea-level rise owing to a combination of limited mineral sedimentation and low root mass accumulation (McKee 2011). Tide-dominated systems occur mostly on higher tidal range coastlines with active tidal currents, where change in sediment supply may cause erosion and mangrove vulnerability.

Sensitivity

Sensitivity refers to innate characteristics of a species or system and considers the degree to which the system is affected by exposure (Turner et al. 2003; Ebi et al. 2006), such as damages caused by an increase in the frequency of coastal flooding due to sea level rise (Intergovernmental Panel on Climate Change (IPCC) 2014). There is a well-researched literature on the influence of environmental conditions on mangrove forest structure, composition and productivity (Clough 1992; Komiyama et al. 2008; Alongi 2009), and similarly interpretation of degree of human impact, and these methods can be applied to climate change sensitivity (Alongi 2008; Pellegrini et al. 2009). Hence vulnerability is shown by decline in forest condition, productivity, biodiversity, and increase in mortality (Table 1), relative to forest biomass or productivity characteristics of pristine mangrove physiognomic types at different latitudes (Lugo and Snedaker 1974; Saenger and Snedaker 1993).

Permanent plots are a well-established technique for long-term monitoring of mangroves (English et al. 1997), and mean diameter at breast height (DBH) or basal area can provide a basis for monitoring status and change in mangrove community structure, biomass, growth and productivity. As forest structural characteristics decrease, productivity from litterfall also decreases (Ntyam et al. 2014). Mean DBH of $>27 \mathrm{~cm}$ identifies maximum structural development and height, intermediate $14.8-4.5 \mathrm{~cm}$, and low structural development 


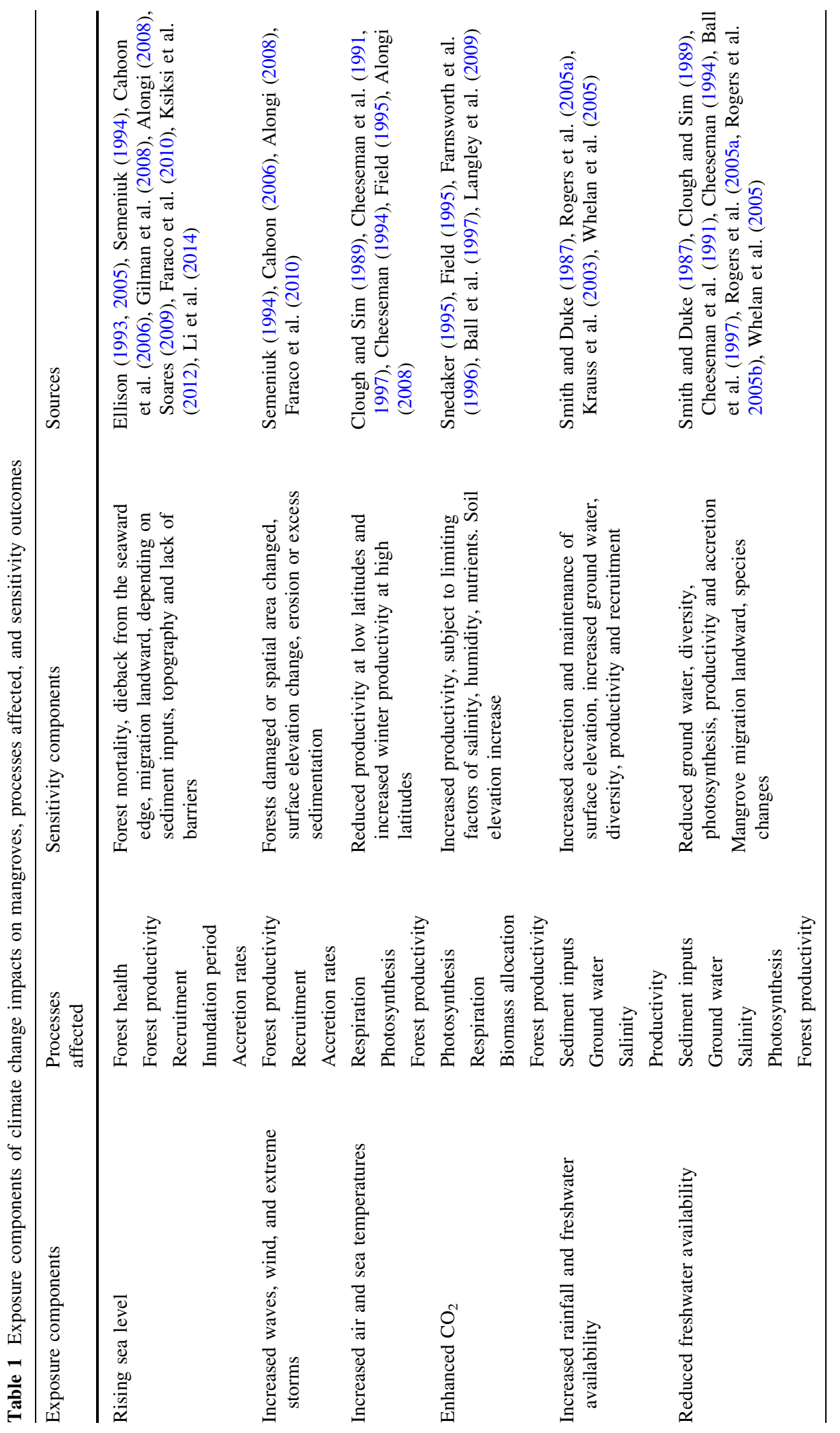


Table 2 Mangrove geomorphic settings and their controlling attributes (adapted from Thom 1984; Ellison 2009)

\begin{tabular}{|c|c|c|c|c|c|}
\hline Attributes & River-dominated & Tide-dominated & Wave-dominated & $\begin{array}{l}\text { River- and wave- } \\
\text { dominated }\end{array}$ & Low island \\
\hline $\begin{array}{l}\text { Geomorphic } \\
\text { setting }\end{array}$ & $\begin{array}{l}\text { Deltaic } \\
\text { distributaries }\end{array}$ & $\begin{array}{l}\text { Estuarine with elongated } \\
\text { islands }\end{array}$ & $\begin{array}{l}\text { Barrier islands/spits and } \\
\text { lagoons }\end{array}$ & $\begin{array}{l}\text { Distributaries and } \\
\text { lagoons }\end{array}$ & $\begin{array}{l}\text { Marine- } \\
\text { dominated }\end{array}$ \\
\hline $\begin{array}{l}\text { Sediment } \\
\text { source }\end{array}$ & Allochthonous & Allochthonous & Autochthonous & Allochthonous & Autochthonous \\
\hline Tidal range & Low & High & Any & Any & Low \\
\hline $\begin{array}{c}\text { Dominant } \\
\text { process }\end{array}$ & $\begin{array}{r}\text { Freshwater } \\
\text { discharge }\end{array}$ & Tidal currents & Wave energy & $\begin{array}{l}\text { Wave energy and } \\
\text { freshwater } \\
\text { discharge }\end{array}$ & Sea level \\
\hline $\begin{array}{l}\text { Mangrove } \\
\text { locations }\end{array}$ & $\begin{array}{l}\text { Seaward edge and } \\
\text { distributaries }\end{array}$ & Tidal creeks and islands & Inside lagoons & $\begin{array}{l}\text { Low energy } \\
\text { distributaries and } \\
\text { lagoons }\end{array}$ & $\begin{array}{l}\text { Fringing or } \\
\text { basin }\end{array}$ \\
\hline $\begin{array}{l}\text { Specific } \\
\text { vulnerability }\end{array}$ & $\begin{array}{l}\text { Change in discharge } \\
\text { and sediment } \\
\text { supply }\end{array}$ & $\begin{array}{l}\text { Increased tidal action; } \\
\text { change in sediment } \\
\text { budgets }\end{array}$ & $\begin{array}{l}\text { Increased wave action; } \\
\text { change in sediment } \\
\text { budgets }\end{array}$ & $\begin{array}{l}\text { Reduction in } \\
\text { sediment supply }\end{array}$ & $\begin{array}{l}\text { Low net } \\
\text { accretion } \\
\text { rates }\end{array}$ \\
\hline
\end{tabular}

gives lower values and indicates mangrove sensitivity to stressors (Pellegrini et al. 2009). Pristine mangrove forests with minimal impacts have been shown to have a basal area of $>25 \mathrm{~m}^{2} \mathrm{ha}^{-1}$ (Komiyama et al. 2008; Kauffman et al. 2011), secondary forest has been found to have basal areas of around $15 \mathrm{~m}^{2} \mathrm{ha}^{-1}$ (Komiyama et al. 2008; Cavalcanti et al. 2009), and disturbed forests show basal areas of $<10 \mathrm{~m}^{2} \mathrm{ha}^{-1}$ (Komiyama et al. 2008), giving guidance to interpretation of forest condition.

Mangrove mortality as a result of exposure factors such as sea level rise or drier conditions causes mangrove area loss or coastal retreat (Giri et al. 2011a), and such shoreline change is an indicator of the risks of sea level rise (Jallow et al. 1999; Freitas et al. 2006; Rao et al. 2008; Dwarakish et al. 2009; Giri et al. 2011a, 2011b; Yin et al. 2012). Spatial change analysis showing mangrove seaward retreat has been attributed to local relative sea-level rise (Gilman et al. 2007; Shearman 2010), or human impacts (Tran Thi et al. 2014), hence it can be utilised as an indicator of mangrove area sensitivity.

\section{Adaptive capacity}

The term adaptation as used in the global change field has its origins in the natural sciences, particularly in evolutionary biology (Smit and Wandel 2006). Adaptive capacity refers to the ability of a species or system to accommodate or cope with climate change impacts with minimal disruption (Glick and Stein 2010). This can be through ecosystem or species response, and through human actions that reduce vulnerability to actual or expected changes in climate.

For mangrove ecosystems, if net vertical accretion does not keep up with relative sea level rise then adaptation is through inland migration, there depending on suitable topography and available areas (Gilman et al. 2008; Faraco et al. 2010). Local communities and stakeholders also develop adaptive capability through their management capacity, supported by effective legislation that enables mangrove protection from non-climate stressors. Effective sustainable management promotes mangrove resilience, a concept linked with adaptive capacity as the ability to absorb and recover from the effects of disturbance (Turner et al. 2003; Intergovernmental Panel on Climate Change (IPCC) 2014).

Vulnerability ranking

Risk-hazard approaches are a classical conceptualisation of vulnerability in its evolution over the last few decades (Füssel 2007). Coastal risk classifications have assigned ranks to variables such as relief, rock type, geomorphology, relative sea level trends, tidal range, shoreline displacement and wave height (Gornitz 1991; Gornitz et al. 1993; Freitas et al. 2006; Diez et al. 2007; Hegde and Reju 2007; Rao et al. 2008; Dwarakish et al. 2009; Abuodha and Woodroffe 2010; 
Pendleton et al. 2010; Ozyurt and Ergin 2010; Yin et al. 2012; Frihy and El-Sayed 2013). Mangrove shorelines were ranked in these as having very high vulnerability (Diez et al. 2007; Hegde and Reju 2007; Rao et al. 2008; Ozyurt and Ergin 2010), and unconsolidated sedimentary shores or coastal wetlands also classified as having very high vulnerability (Gornitz 1991; Gornitz et al. 1993; Freitas et al. 2006; Dwarakish et al. 2009). The assigning of rank was developed because such vulnerability databases comprise both qualitative as well as quantitative information (Gornitz 1991).

Relative sea level rise is a key variable to a coastal risk assessment (Gornitz et al. 1993; Diez et al. 2007; Yin et al. 2012; Frihy and El-Sayed 2013), incorporating local factors such as long term regional downwarping and sediment compaction that contribute to subsidence. On coasts such as the US these trends can be interpreted from tide gauge records (Gornitz et al. 1993), with the Chinese coast having 52 long term tide gauges from which to determine relative sea level change risks (Yin et al. 2012). For mangroves, many tropical shorelines lack such long-term gauges (Gilman et al. 2006; Mcleod et al. 2010), so relative sea level trends derived from tide gauges cannot be included in a coastal vulnerability assessment (Gravelle and Mimura 2008; Al-Jeneid et al. 2008; Rao et al. 2008; Ksiksi et al. 2012). Relative sea level trends in mangrove environments can however be reconstructed from palaeoecological records, if such sea level indicator points are accurately related to tidal datum (Ellison 2005).

The variable of tidal range has been interpreted differently in coastal vulnerability assessments. Some ranked microtidal range as low risk and macrotidal range as very high risk (Gornitz 1991, Gornitz et al. 1993; Diez et al. 2007; Rao et al. 2008; Yin et al. 2012). This was justified because macrotidal ranges result in a broad zone of intertidal wetlands, which increase inundation hazards (Diez et al. 2007), and also are associated with strong tidal currents capable of erosion (Gornitz 1991, Gornitz et al. 1993). Others assigned microtidal range to be high risk and macrotidal range to be low risk (Dwarakish et al. 2009; Ozyurt and Ergin 2010), considering that microtidal coasts are more vulnerable to storm impacts as water level is always within a meter or so of high tide, whereas on a $4 \mathrm{~m}$ tidal range shoreline there is $50 \%$ chance that the tidal level will be $2 \mathrm{~m}$ below high tide level when a storm hits (Dwarakish et al. 2009).

In mangroves, tidal range and coastal gradient control the lateral extent of the swamp as well as species zones within the mangroves, with mangroves primarily located between mean sea level and high tide elevations (Ellison 2009). Assuming similar gradients, mangroves in macrotidal areas have a greater lateral extent than mangroves in microtidal areas (Fig. 2). Relative sea level rise causes upward movement of the tidal range, introducing a range in vulnerability of mangroves to relative sea level rise demonstrated in Fig. 2, in that that a sea level rise will cause a greater relocation of intertidal habitats in microtidal areas relative to macrotidal areas. Assuming similar low net vertical accretion to clarify this point, a $1 \mathrm{~m}$ sea-level rise by 2100 will only cause a partial relocation of mangroves in a $4 \mathrm{~m}$ tidal range area, but a total relocation in a $1 \mathrm{~m}$ tidal range area. Mangrove surface gradients in Fig. 2 are vertically exaggerated relative to those found in mangrove systems, with typical mangrove gradients being very low, such as c. $0.01 \%$ (Ellison 2005). Hence horizontal relocation with $1 \mathrm{~m}$ of relative sea level rise would be very significant. Successful mangrove ecosystem relocation requires not only habitat availability, but also mangrove soil formation with suitable soil physio-chemical properties, and successful migration and establishment of ecosystem associates.

Vulnerability assessment

Participatory vulnerability assessments allow for the recognition of multiple stimuli beyond those related to climate (Smit and Wandel 2006), and vulnerability assessments of mangroves to climate change have been recognised by UNEP as necessary to be able to provide early warning and remedial measures (Diop 2003). While mangrove vulnerability and adaptation options have been reviewed (McLeod and Salm 2006; Gilman et al. 2006; Lovelock and Ellison 2007; Gilman et al. 2008; Gehrke et al. 2011; Waycott et al. 2011; Ellison 2014a), these did not extend into recognised dimensions, components and measurements of vulnerability as described by Polsky et al. (2007) to allow a generalised replicable approach.

A risk ranking system for mangroves could identify aspects of the forest system most susceptible to 


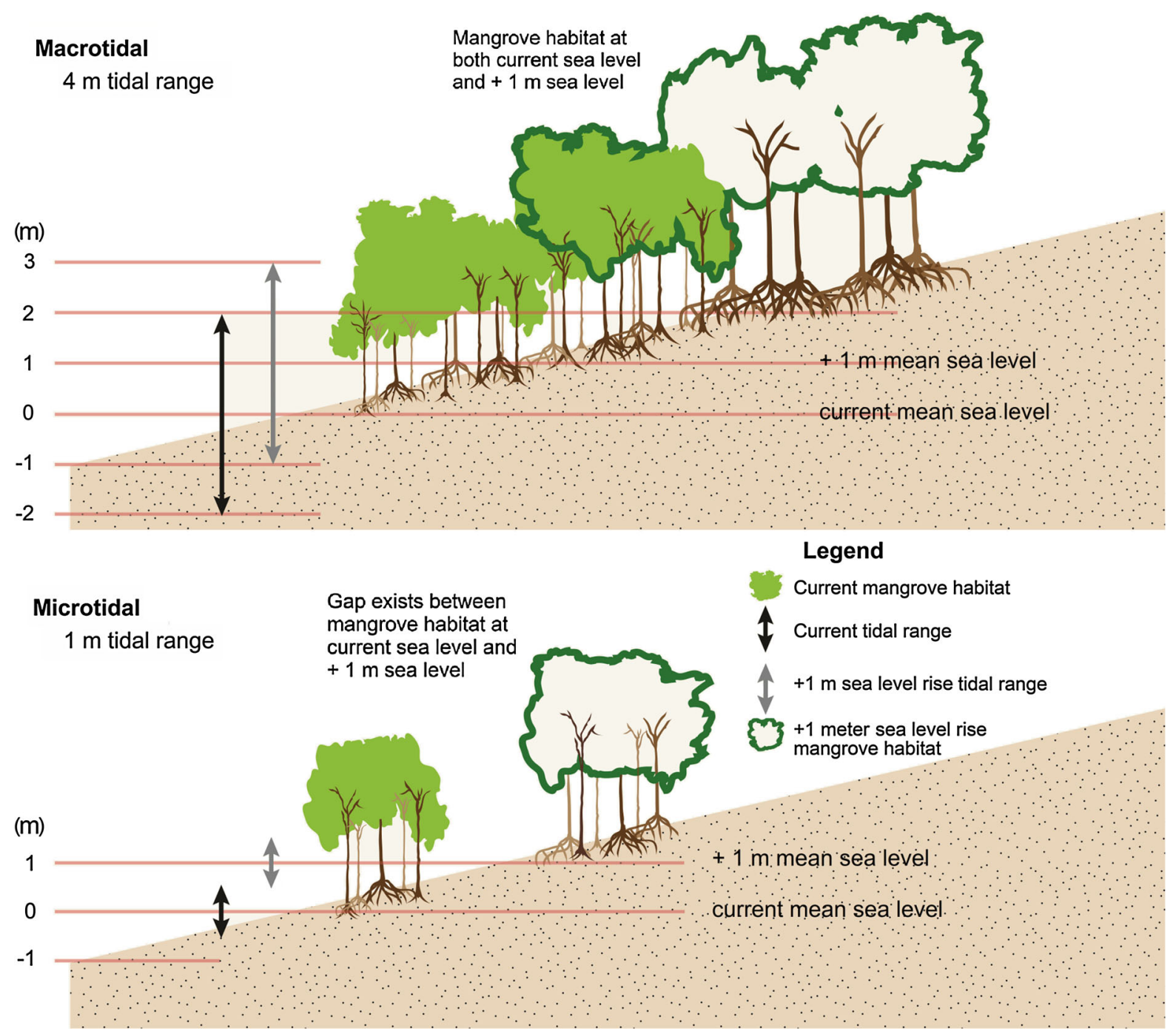

Fig. 2 Comparison of sea level rise relocation of the mangrove habitat in macrotidal relative to microtidal settings

disturbance under a changing climate (Dale et al. 2001), and the strengthening of management frameworks to conduct site specific assessment of mangrove vulnerability including the use of results in planning has been identified as a need by many Pacific island mangrove managers (Gilman et al. 2006). Vulnerability protocols that couple ecosystem research and socioeconomic scenarios have also been identified as a need for African countries (Dixon et al. 2003). Identification of appropriate metrics for measuring mangrove vulnerability to effects of climate change is a critical need for designing climate-smart conservation (Hansen et al. 2010).

\section{Objective}

The objective of this study was to investigate components of a climate change mangrove vulnerability assessment through measurements at several sites, and develop an analysis procedure to allow mangrove managers to identify specific vulnerabilities, to facilitate strategic management planning. With coastal risk classifications placing mangroves among the highest ranked of shoreline types in their vulnerability, this study develops a higher resolution of ranking within such mangrove shorelines, using the most relevant of risk variables combined with measurements of 


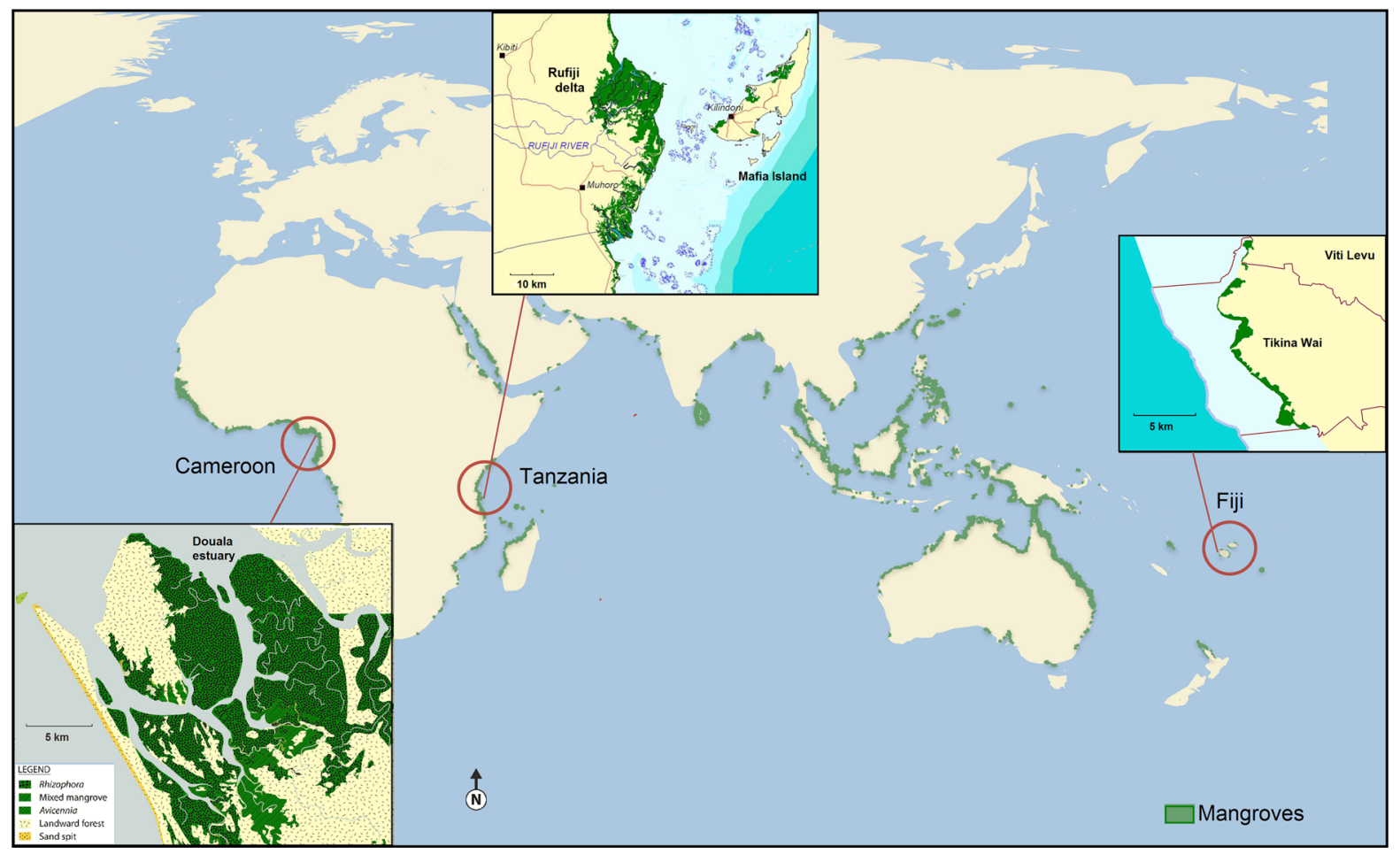

Fig. 3 Location of primary mangrove vulnerability assessment trial sites

components of mangrove exposure, sensitivity and adaptive capacity.

\section{Methods}

\section{Study areas}

Mangrove vulnerability assessment trials were conducted through World Wildlife Fund (WWF) program offices over a 4 year period in three countries of Africa and the Pacific Islands: Cameroon, Tanzania, and Fiji (Fig. 3; Table 3). These sites were selected for the following reasons:

1. Tropical Africa and the South Pacific are particularly vulnerable to global climate change (Dixon et al. 2003; Gilman et al. 2006; IPCC 2007), because of physical and geographical characteristics and low institutional capacity (Heileman and Cabanban 2013).
2. All the sites are deltaic/estuarine and so represent the most extensive types of mangroves worldwide (Giri et al. 2011a).

3. All the sites have a comparable number of six to eight true mangrove species, one having Atlantic species and two having eastern Asian species (Table 3).

4. All the sites lack a record of relative sea level trends from long term tide gauges, which is typical of most mangrove coastlines of the world, providing an opportunity to investigate alternate methods.

5. Two of the sites have microtidal ranges, which for mangrove systems are likely to be most vulnerable to sea level rise.

6. The sites are occupied by traditional cultures that are dependent on the natural resources provided by healthy coastal ecosystems.

Primary sites were selected in each country, each with the criteria of being a significant mangrove area with a resource-dependent community having previous involvement with resource management projects. 


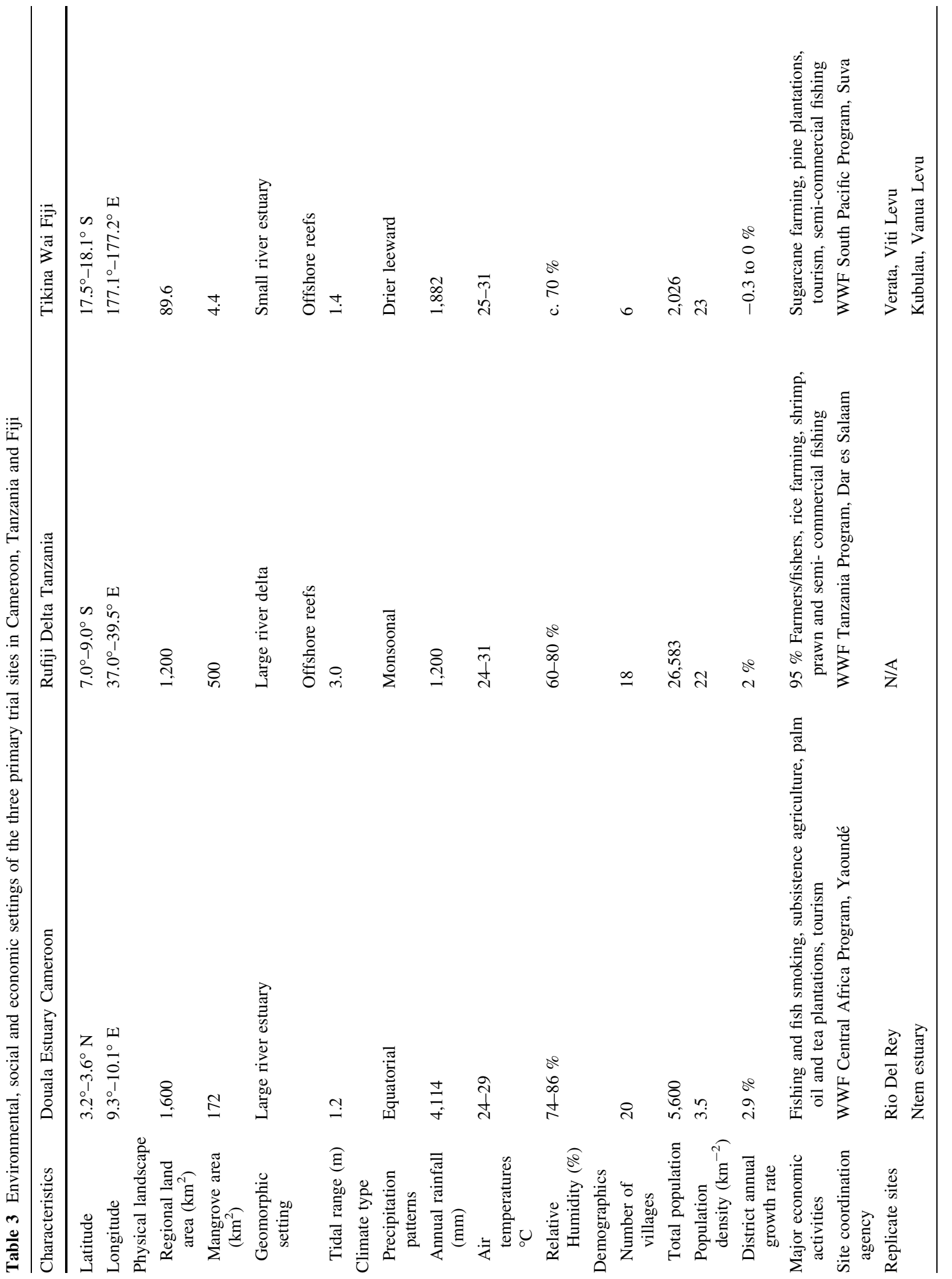


In Tanzania this was the largest mangrove area in the country with some variety across its expanse, and in Cameroon and Fiji most vulnerability assessment components were trialled at two further sites.

\section{Vulnerability assessment methodology}

The vulnerability assessment methodology was designed to identify components of the mangrove system that may be already experiencing climate change impacts, and which were most vulnerable to future impacts. An interdisciplinary combination of approaches was trialled (Table 4), preceded by an initial review existing information of relevance (e.g. Ellison and Fiu 2010). The desktop review of existing information also fulfilled steps necessary before a vulnerability assessment (Schröter et al. 2005), of stakeholder involvement and site definition. Field and analysis methods for each trialled component are provided in the sources listed in Table 4, and described in Ellison (2012).

To obtain an overall mangrove vulnerability assessment, results from the measured components of vulnerability (Table 4) were assigned ranks based on guidance from the literature (Tables 1,2). Rank criteria developed for each vulnerability dimension at each site are shown in Table 5, where 1 is low vulnerability and 5 is high, and results were averaged to give an overall vulnerability rank:

Vulnerability rank
$=\frac{\text { Total of component rank scores }}{\text { Number of components completed }}$.

Figure 1 identified the three vulnerability dimensions, Tables 2 and 4 defined their components for mangrove systems, and Fig. 4 adds the measures used for mangrove vulnerability components in this study. This approach builds a vulnerability scoping diagram (Polsky et al. 2007) that allows comparable approaches to vulnerability assessment in different settings, here applied to mangrove systems (Fig. 4). Applications of this approach have included climate change impacts on water supply, coastal tourism (Moreno and Becken 2009), the wine industry (Nicholas and Durham 2012) as well as vulnerability to hurricane impacts (Wang and Yarnal 2012) among others.

Stakeholder groups were involved in each country throughout planning and implementation stages, with workshops used at the commencement of the vulnerability assessment for scoping and information-sharing. Stakeholder contributions were enabled by ongoing communication through facilitator consultation, emails, meetings and sharing of reports and results. Towards the end of the assessment, workshops contributed the vulnerability assessment findings to regional scale planning, the improvement of policy and the identification of management priorities to promote adaptation measures. Stakeholder involvement, local management capacity and effectiveness of legislation in the mangrove area was assessed from results of structured interviews with stakeholders and local community members, with ranking allowing comparison of qualitative and quantitative information (Gornitz 1991).

\section{Results}

Primary sites at Douala Estuary, Cameroon and Tikina Wai, Fiji were within $30 \mathrm{~km}$ of a high technology tide gauge from which tidal range could be determined, but both were of too short a record from which to gain a relative sea level trend (Pugh 1987). Rufiji Delta was remote from tide gauge records so at all sites relative sea level trends were interpreted from mangrove palaeoecological reconstruction (Ellison and Zouh 2012; Punwong et al. 2013; Ellison and Strickland 2013). All primary sites were located in deltaic or estuarine geomorphic settings, with fluvial sediment supply, which was confirmed by high inorganic content in mangrove sediments. It was found that available precipitation modelling results were of insufficient detail and certainty to assess potential vulnerability (Fiu et al. 2010), or only indicating changes in rainfall timing in the case of Tanzania (Taylor 2011). As rainfall projections improve in future, this component could be better incorporated in future mangrove assessments.

For forest assessment, at Douala in Cameroon, mangrove forest measurements of basal area, mortality and recruitment trends were carried out at nine permanent sample plots of 0.1 ha in size, including incorporation of plots already established (Ajonina 2008) to allow a 7-8 years repeat measurement (Ajonina and Chuyong 2011; Ajonina et al. 2014). In Fiji, similar forest assessments were carried out at Tikina Wai, of forest community structure, height and 
Table 4 Components and measurement techniques used in mangrove vulnerability assessment

\begin{tabular}{|c|c|c|c|}
\hline $\begin{array}{l}\text { Dimension } \\
\text { of } \\
\text { Vulnerability }\end{array}$ & Component & Measurement & Sources \\
\hline \multirow[t]{4}{*}{ Exposure } & $\begin{array}{l}\text { Relative sea } \\
\text { level trends }\end{array}$ & $\begin{array}{l}\text { Tide gauge records, or stratigraphy, } \\
\text { radiocarbon dating and pollen analysis }\end{array}$ & $\begin{array}{l}\text { Ellison and Zouh (2012), Punwong et al. (2013), } \\
\text { Ellison and Strickland (2013) }\end{array}$ \\
\hline & Tidal range & Tide gauge records & Permanent Service for Mean Sea Level 2014 \\
\hline & $\begin{array}{l}\text { Sediment } \\
\text { supply type }\end{array}$ & Assessment of geomorphic setting & Table 2 \\
\hline & $\begin{array}{l}\text { Precipitation } \\
\text { change }\end{array}$ & $\begin{array}{l}\text { Assessment of available climate (rainfall) } \\
\text { projections }\end{array}$ & Fiu et al. (2010), Taylor (2011) \\
\hline \multirow[t]{6}{*}{ Sensitivity } & $\begin{array}{l}\text { Mangrove } \\
\text { forest health }\end{array}$ & $\begin{array}{l}\text { Transect-based permanent plots, and rapid } \\
\text { condition assessment methods. Mangrove } \\
\text { basal area and change trends, recruitment, } \\
\text { mortality, mangrove productivity }\end{array}$ & $\begin{array}{l}\text { Ajonina (2008), Ajonina et al. (2009), Wagner } \\
\text { and Sallema-Mtui (2010), Fiu et al. (2010), } \\
\text { Ajonina and Chuyong (2011), Ellison et al. } \\
\text { (2012), Ajonina et al. (2014) }\end{array}$ \\
\hline & $\begin{array}{l}\text { Seaward edge } \\
\text { retreat }\end{array}$ & $\begin{array}{l}\text { Recent spatial changes of mangroves; air } \\
\text { photograph and satellite image analysis of }\end{array}$ & $\begin{array}{l}\text { Wagner and Sallema-Mtui (2010), Ellison and } \\
\text { Zouh (2012), Burgess et al. (2013) }\end{array}$ \\
\hline & $\begin{array}{l}\text { Reduction in } \\
\text { mangrove } \\
\text { area }\end{array}$ & change by GIS & \\
\hline & $\begin{array}{l}\text { Elevations } \\
\text { within the } \\
\text { mangroves }\end{array}$ & Topographic survey & $\begin{array}{l}\text { Ellison and Zouh (2012), Ellison and Strickland } \\
\text { (2013) }\end{array}$ \\
\hline & $\begin{array}{l}\text { Net accretion } \\
\text { rates under } \\
\text { mangroves }\end{array}$ & $\begin{array}{l}\text { Radiocarbon dates on stratigraphy, } \\
\text { sedimentation rods }\end{array}$ & $\begin{array}{l}\text { Fiu et al. (2010), Ellison and Zouh (2012), } \\
\text { Punwong et al. (2013), Ellison and Strickland } \\
\text { (2013) }\end{array}$ \\
\hline & $\begin{array}{l}\text { Adjacent } \\
\text { ecosystem } \\
\text { resilience }\end{array}$ & $\begin{array}{l}\text { Coral reef and seagrass monitoring standard } \\
\text { methods }\end{array}$ & Fiu et al. (2010), Obura (2010) \\
\hline \multirow[t]{4}{*}{$\begin{array}{l}\text { Adaptive } \\
\text { capacity }\end{array}$} & $\begin{array}{l}\text { Mangrove } \\
\text { protection } \\
\text { status }\end{array}$ & $\begin{array}{l}\text { Compilation of local community knowledge; } \\
\text { facilitated workshops; structured } \\
\text { questionnaire surveys }\end{array}$ & $\begin{array}{l}\text { Ajonina et al. (2009), Fiu et al. (2010), Wagner } \\
\text { and Sallema-Mtui (2010) }\end{array}$ \\
\hline & $\begin{array}{l}\text { Local } \\
\text { management } \\
\text { capacity }\end{array}$ & & \\
\hline & $\begin{array}{l}\text { Stakeholder } \\
\text { involvement }\end{array}$ & & \\
\hline & $\begin{array}{l}\text { Elevations } \\
\text { above the } \\
\text { mangroves }\end{array}$ & Topographic survey & Kimeu and Machano (2011) \\
\hline
\end{tabular}

diameter, and density of seedlings, with measurements repeated 2 years later (Fiu et al. 2010). The local community was involved in assessment of mangrove condition and collection of productivity monitoring data per $\mathrm{m}^{2}$ to indicate vegetative production and the timing of flowering and fruiting. In Tanzania, mangrove forest measurements were carried out 2007-2009 at 480 permanent plots at 20 sites across the delta in shore-normal transects (Wagner and Sallema-Mtui 2010), combined with a more widescale assessment of mangrove condition.
Spatial change analysis of the Douala Estuary mangroves 1975-2010 showed some seaward edge retreat but stable landward margins (Ellison and Zouh 2012). Recent spatial changes in mangrove areas of all three Fiji sites were carried out by the Wildlife Conservation Society and University of the South Pacific using GIS analysis to show little change over the last several decades (Fiu et al. 2010). In Tanzania, analysis of satellite images showed a moderate reduction in mangrove area including seaward edge retreat in the last decade (Wagner and Sallema-Mtui 


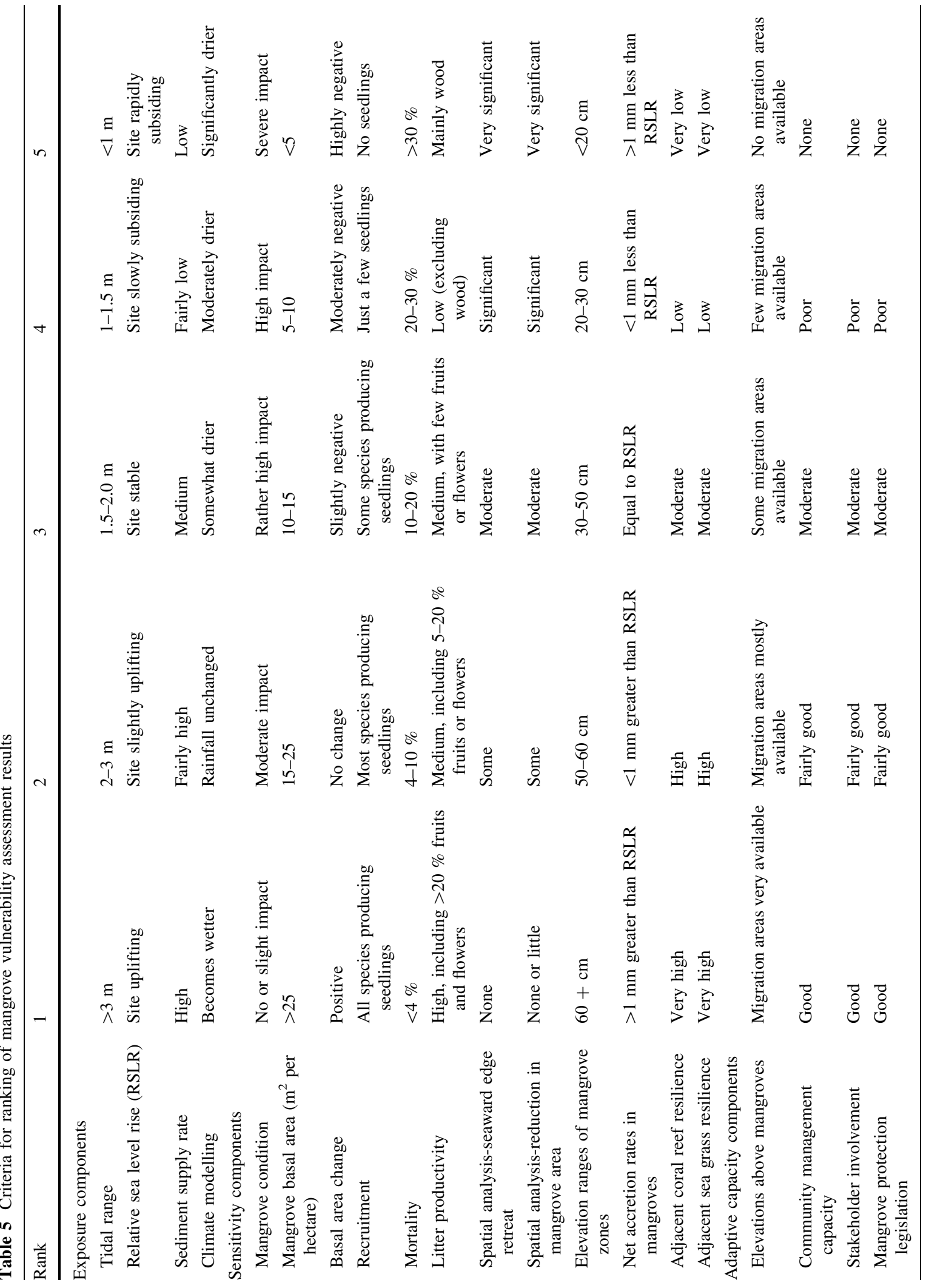


Fig. 4 Vulnerability scoping diagram for mangrove systems

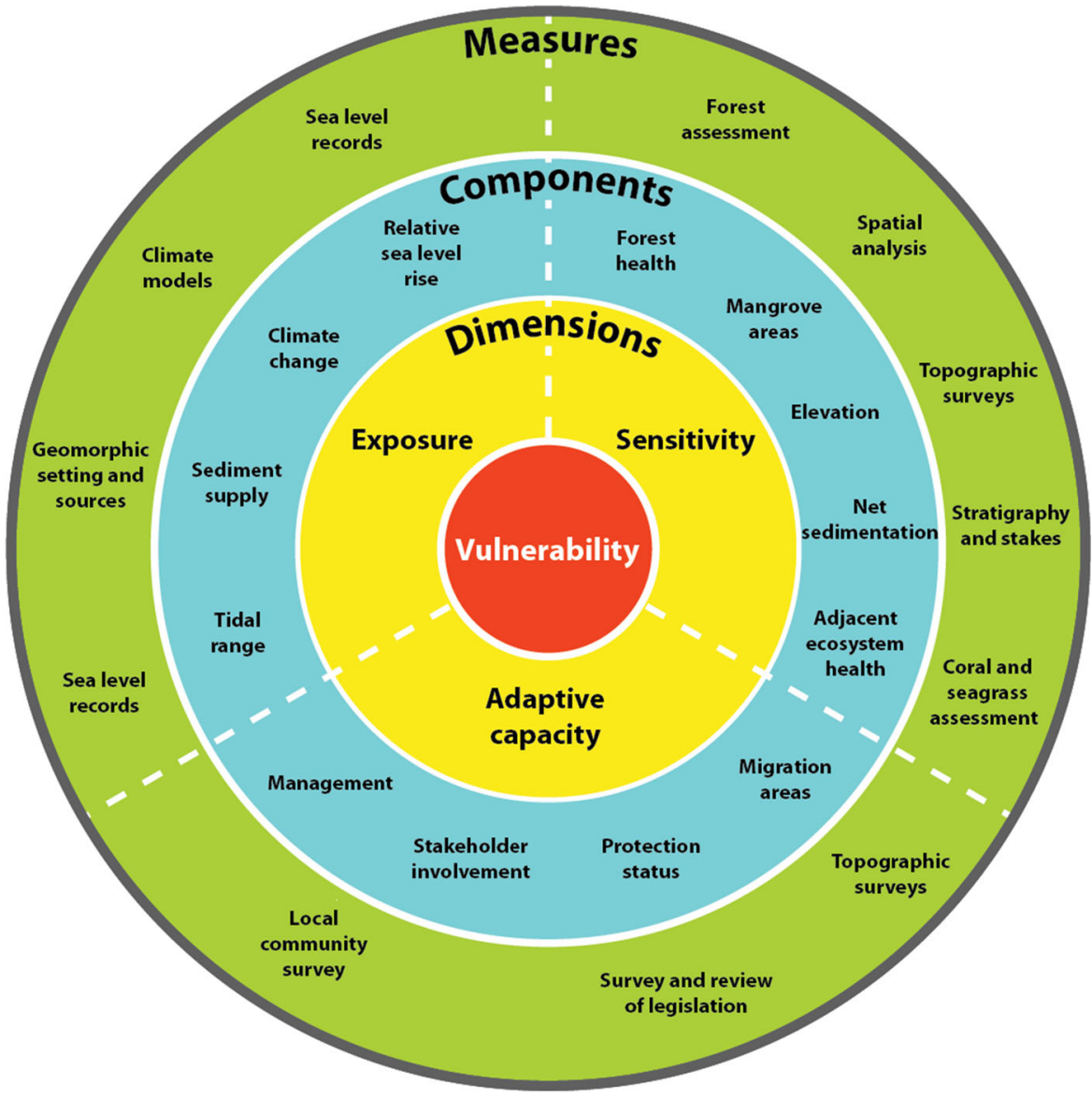

2010), and 20 years of analysis showed landward mangrove loss with rice farming expansion (Burgess et al. 2013). Mangrove area reduction trends were also found in an earlier study (Wang et al. 2003).

Elevations within the mangrove zones were surveyed as part of relative sea level reconstructions (Ellison and Zouh 2012; Ellison and Strickland 2013), finding both in Cameroon and Fiji that Rhizophora genera occupied the greater elevational ranges, of $48 \mathrm{~cm}$ in Cameroon and $100 \mathrm{~cm}$ in Fiji. Other species zones showed tighter elevational ranges, with Bruguiera within $60 \mathrm{~cm}$ in Fiji and Avicennia and Laguncularia occupying less than $20 \mathrm{~cm}$ in Cameroon. Potential migration areas were surveyed inland of the northern Rufiji Delta using differential GPS (Kimeu and Machano 2011; Ellison 2012). Results showed available low gradient areas $(0.02 \%)$ inland of current mangroves at incremental elevations up to $1 \mathrm{~m}$ above highest high water, with lack of barriers to migration such as roads or railways.
Net accretion rates under mangroves at Tikina Wai were monitored over several years using deeply inserted rods (Fiu et al. 2010), with results showing some variable surface elevation changes. Net long term accretion rates in stratigraphy under central and landward mangroves were found to be 1.1-2.0 $\mathrm{mm} \mathrm{a}^{-1}$, and pollen analysis showed that mangrove zones have not quite kept up with relative sea level rise of $2.1 \mathrm{~mm} \mathrm{a}^{-1}$, with mangrove zones retreating landwards (Ellison and Strickland 2013). In the Rufiji Delta, Punwong et al. (2013) showed landward and seaward mangrove stratigraphy to have net accretion rates of $3 \mathrm{~mm} \mathrm{a}^{-1}$, and like Tikina Wai dominated by inorganic sources. At Douala, Cameroon, net accretion rates under mangroves were found to be c. $2.6 \mathrm{~mm} \mathrm{a}^{-1}$ (Ellison and Zouh 2012; Ellison, in press). Net accretion rates can be interpreted from stratigraphy (McKee et al. 2007) as a low cost alternative to use of surface elevation tables, though use of such methodology would allow interpretation of 
the contributing factors to surface elevation change and variation over time (Rybczyk and Callaway 2009; Krauss et al. 2010).

At Tikina Wai, extensive seagrass and coral reef surveys were conducted along the mangrove coastline of adjacent ecosystem health in the area, with an initial inventory in 2007 and a second monitoring survey in 2008 (Fiu et al. 2010). Coral reef inventories utilised earlier monitoring by WWF going back to 2002, and found that the condition of offshore reefs has remained resilient, while inshore seagrass beds showed some impacts in particular from sedimentation. At key coral reef sites offshore of the Rufiji mangrove area, a reef baseline inventory was carried out in 2007 and repeated in 2009 (Obura 2010), finding reefs to be in good condition and on a recovery trajectory from a previous coral bleaching event. Both coral reef reports from Fiji and Tanzania commented on the protective functions that coastal mangroves provide to offshore coral reef health.

Overall ranking results derived from each primary site (Fig. 3; Table 3) are shown in Table 6 using the rank criteria for analysis of each measurement (Table 5) to interpret results from each site. Sources giving details of results from each component are given in Table 4. Some site assessments could not complete all components of the vulnerability assessment, due to limited budgets or the mangrove site not having adjacent coral reefs. Rank results are averaged in the last row of Table 6 to give an overall vulnerability rank for each site.

Figure 5 shows a vulnerability triangle plotting the mean of rank results for exposure, sensitivity and adaptive capacity (Table 6), following Hahn et al. (2009), where the greater area of the triangle shows greater vulnerability. It shows that mangroves of Tikina Wai, Fiji have most exposure to climate change and sea level rise impacts of the three study sites, followed closely by Douala, Cameroon, while exposure at Rufiji, Tanzania is lower. Cameroon leads the other two sites in vulnerability as a result of sensitivity and adaptive capacity components.

\section{Discussion}

Results of the vulnerability assessment ranking using up to 20 measurements found all sites to have some components of vulnerability (Table 6), where 1 is low vulnerability and 5 is very high vulnerability (Table 5). Ranks of 1-2 indicate mangrove areas that have current resilience, which could be enhanced by reducing the rank of any vulnerability components that are higher than 1. Ranks of 2-4 would indicate some core vulnerability that targeted management could improve. Vulnerability ranks of above four would indicate mangroves with very high vulnerability, requiring immediate management actions.

The Douala Estuary mangroves of Cameroon were found to have some inherent vulnerability due to the low tidal range (Table 6), and showing moderate seaward edge retreat (Ellison and Zouh 2012). Vulnerability could be reduced by better control of non-climate stressors to increase the resilience of habitats and species to the effects of climate change (Erwin 2009), which can be achieved through improvement of local management and reduction of human impacts (Ajonina et al. 2009). Priorities for management in mangrove areas located in such low tidal range regions are to plan inland migration areas and strategic mangroves protected areas, and to undertake management activities that enhance vertical accretion within the mangroves (Ellison and Zouh 2012). Planning inland migration areas could consider removal of barriers to migration and engage collaborative planning of suitable areas with local communities. Mangrove protected areas that are strategic during climate change are those with a reliable sediment supply and high species diversity. Strategies to promote mangrove substrate accretion are summarised in Fig. 6.

The Rufiji mangroves have some inherent resilience, with a higher tidal range than Cameroon or Fiji, positioned at the delta of a major river with high sediment inputs, and apparently experiencing slight longterm tectonic uplift (Punwong et al. 2013). The river catchment is not currently predicted to receive reduced rainfall as a result of climate change, although there is uncertainty (Taylor 2011). Much of the delta is also relatively sheltered from storm effects by the large Mafia Island offshore (Fig. 3). While GIS analysis and forest assessment results showed resilience in the majority of the mangrove area, there have been losses of mangroves on the landward margins owing to human disturbance, particularly from the conversion of mangrove habitat to rice cultivation (Burgess et al. 2013). The vulnerability of the mangrove areas in the Rufiji Delta can be reduced 
Table 6 Vulnerability assessment ranking results for the three primary study sites. Rank results are averaged in the last row to give an overall vulnerability rank for each site, shown in bold

\begin{tabular}{|c|c|c|c|}
\hline Components & Douala Estuary, Cameroon & Rufiji Delta, Tanzania & Tikina Wai, Fiji \\
\hline \multicolumn{4}{|l|}{ Exposure } \\
\hline Tidal range & $4(1-1.5 \mathrm{~m})$ & $1(>3 \mathrm{~m})$ & $4(1-1.5 \mathrm{~m})$ \\
\hline $\begin{array}{l}\text { Relative sea level rise } \\
\text { (RSLR) }\end{array}$ & 3 (Site stable) & 2 (Site slightly uplifting) & 4 (Site slowly subsiding) \\
\hline Sediment supply rate & 2 (Fairly high) & 2 (Fairly high) & 4 (Fairly low) \\
\hline Climate modelling & $\mathrm{n} / \mathrm{a}$ & 2 (Rainfall unchanged) & $\mathrm{n} / \mathrm{a}$ \\
\hline \multicolumn{4}{|l|}{ Sensitivity } \\
\hline Mangrove condition & 2 (Moderate impact) & 1 (No or slight impact) & 1 (No or slight impact) \\
\hline $\begin{array}{l}\text { Mangrove basal area }\left(\mathrm{m}^{2} \text { per }\right. \\
\text { hectare })\end{array}$ & $2(15-25)$ & $2(15-25)$ & $1(>25)$ \\
\hline Basal area change & 1 (Positive) & 1 (Positive) & 1 (Positive) \\
\hline Recruitment & $\begin{array}{l}2 \text { (Most species producing } \\
\text { seedlings) }\end{array}$ & $\begin{array}{l}1 \text { (All species producing } \\
\text { seedlings) }\end{array}$ & 1 (All species producing seedlings) \\
\hline Mortality & $1(<4 \%)$ & $1(<4 \%)$ & $1(<4 \%)$ \\
\hline Litter productivity & $\mathrm{n} / \mathrm{d}$ & $\mathrm{n} / \mathrm{d}$ & $\begin{array}{l}1 \text { (High, including }>20 \% \text { fruits and } \\
\text { flowers) }\end{array}$ \\
\hline GIS-seaward edge retreat & 2 (Some) & 2 (Some) & 1 (None) \\
\hline $\begin{array}{l}\text { GIS-reduction in mangrove } \\
\text { area }\end{array}$ & 1 (None or little) & 3 (Moderate) & 1 (None or little) \\
\hline $\begin{array}{l}\text { Elevation ranges of mangrove } \\
\text { zones }\end{array}$ & $4(30-50 \mathrm{~cm})$ & $1(60+\mathrm{cm})$ & $2(50-60 \mathrm{~cm})$ \\
\hline $\begin{array}{l}\text { Net accretion rates in } \\
\text { mangroves }\end{array}$ & 3 (Equal to RSLR) & $\begin{array}{l}1 \text { ( }>1 \mathrm{~mm} \text { Greater than } \\
\text { RSLR) }\end{array}$ & 4 ( $<1 \mathrm{~mm}$ Less than RSLR) \\
\hline Adjacent coral reef resilience & $\mathrm{n} / \mathrm{a}$ & 2 (High) & 1 (Very high) \\
\hline Adjacent sea grass resilience & $\mathrm{n} / \mathrm{a}$ & $\mathrm{n} / \mathrm{d}$ & 3 (Moderate) \\
\hline \multicolumn{4}{|l|}{ Adaptive capacity } \\
\hline Elevations above mangroves & $\begin{array}{l}3 \text { (Some migration areas } \\
\text { available) }\end{array}$ & $\begin{array}{l}1 \text { (Migration areas very } \\
\text { available) }\end{array}$ & 3 (Some migration areas available) \\
\hline $\begin{array}{l}\text { Community management } \\
\text { capacity }\end{array}$ & 2 (Fairly good) & 4 (Poor) & 1 (Good) \\
\hline Stakeholder involvement & 2 (Fairly good) & 3 (Moderate) & 1 (Good) \\
\hline $\begin{array}{l}\text { Mangrove protection } \\
\text { legislation }\end{array}$ & 3 (Moderate) & 1 (Good) & 3 (Moderate) \\
\hline Total & 37 & 30 & 38 \\
\hline Number of components & 16 & 18 & 19 \\
\hline Vulnerability rank & 2.3 & 1.8 & 2.0 \\
\hline
\end{tabular}

through further efforts by local communities and stakeholders to replant degraded mangrove areas (Burgess et al. 2013), to enhance accretion though root mat growth and sediment trapping in root systems.

The mangrove areas of Tikina Wai, Fiji, show inherent vulnerability owing to their location on a subsiding coastline along with a low tidal range (Table 6). However, the area showed lack of spatial change over the last few decades and strong involvement of local communities in mangrove, seagrass and reef management (Fiu et al. 2010). Vulnerability could be reduced by further enhancing local management capacity to reverse offshore seagrass degradation, as seagrass provides a sediment supply to mangroves. As for Cameroon, promotion of surface elevation increase would reduce vulnerability (Ellison and Strickland 2013), and with mangrove sediment showing a high 


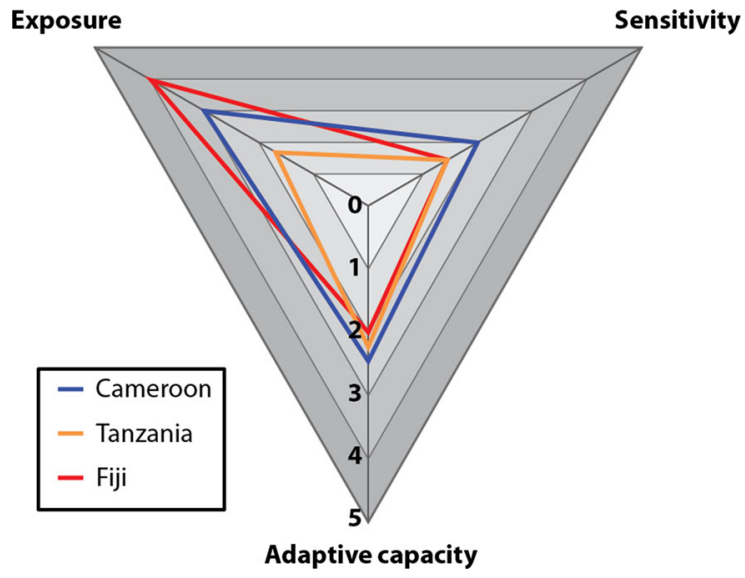

Fig. 5 Vulnerability triangle showing results from Cameroon, Fiji and Tanzania mangrove assessments

proportion of inorganic sediment in mangrove substrate there is capacity to increase net vertical accretion by increased autochthonous contribution (Fig. 6). The vulnerability of Tikina Wai could be further reduced by planning of inland migration areas and by working with the government to improve mangroverelated protection legislation to reduce non-climate stressors.

The most critical components to the vulnerability assessment were found to be the exposure components of relative sea level trends and sediment supply (Table 1), and the sensitivity components of forest health, recent spatial changes and net sedimentation rates. These are likely to be the components in the mangrove ecosystem (Table 1) that lead to an ecosystem regime shift or "tipping point" (Lenton et al. 2008; Eslami-Andergoli et al. 2014), whereas other components are those that contribute to vulnerability but are less critical. Other studies (Rao et al. 2008; Hahn et al. 2009; Yin et al. 2012) have used weighting of more critical components such as spatial change and coastal slope in a vulnerability assessment. Use of a vulnerability ranking average in this study makes the component ranking method easily adjustable if a component is either not relevant to the mangrove area or is not able to be carried out, and keeps the calculation easy to use by mangrove managers. Hence weighting was achieved by assigning more than one ranked measurement to these critical components, such as both seaward edge retreat and reduction in mangrove area from the analysis of spatial change over time (Tables 4,5 ).

Vulnerability components found to be of higher rank relative to others can be specifically targeted in prioritisation of management decisions (Ellison 2012; 2014b). Targeted management strategies can reduce any identified vulnerability, of components giving higher rank results, such as two or above (Table 5) with a management objective of reducing that rank from higher to lower. Exposure components are not able to be reduced because they are extrinsic to the system, such as tidal range and sediment supply type, as these are a consequence of the geomorphic setting and the mangrove area's location. Adaptive capacity to the higher ranked exposure components can however be improved by management actions, such as planning inland migration areas or actions to enhance the net sedimentation rate (Fig. 6). Sensitivity components that are found to be of a higher rank vulnerability can be improved by mangrove managers, such as reduction in nonclimate stressors that may be impacting mangrove forest health, and rehabilitation of degraded areas through mangrove planting.

Effective legislation and management capacity can either contribute to sensitivity or adaptive capacity in mangrove vulnerability (Faraco et al. 2010). This study included these components in the dimension of adaptive capacity, as effectiveness of legislation or management capacity through sustainable use of mangrove resources can be a sensitivity component if the situation is poor, or more proactively become an adaptive capacity component that could reduce sensitivity. Similarly, sedimentation rates in mangroves can be an adaptive capacity factor ( $\mathrm{Li}$ et al. 2014) if this can keep pace with relative sea level rise, or a sensitivity factor if not. As sedimentation is linked to associated components of elevations and forest health, and is affected by the exposure component of rising sea level through reduction in root mat growth and increase in surface compaction, this study found it to be a better precaution to retain it as a sensitivity component.

The vulnerability trials conducted in this study found that the criteria that should guide a vulnerability assessment described by Schröter et al. (2005) were applicable to mangrove areas. Applying those general guidelines, and incorporating guidance concluded by 


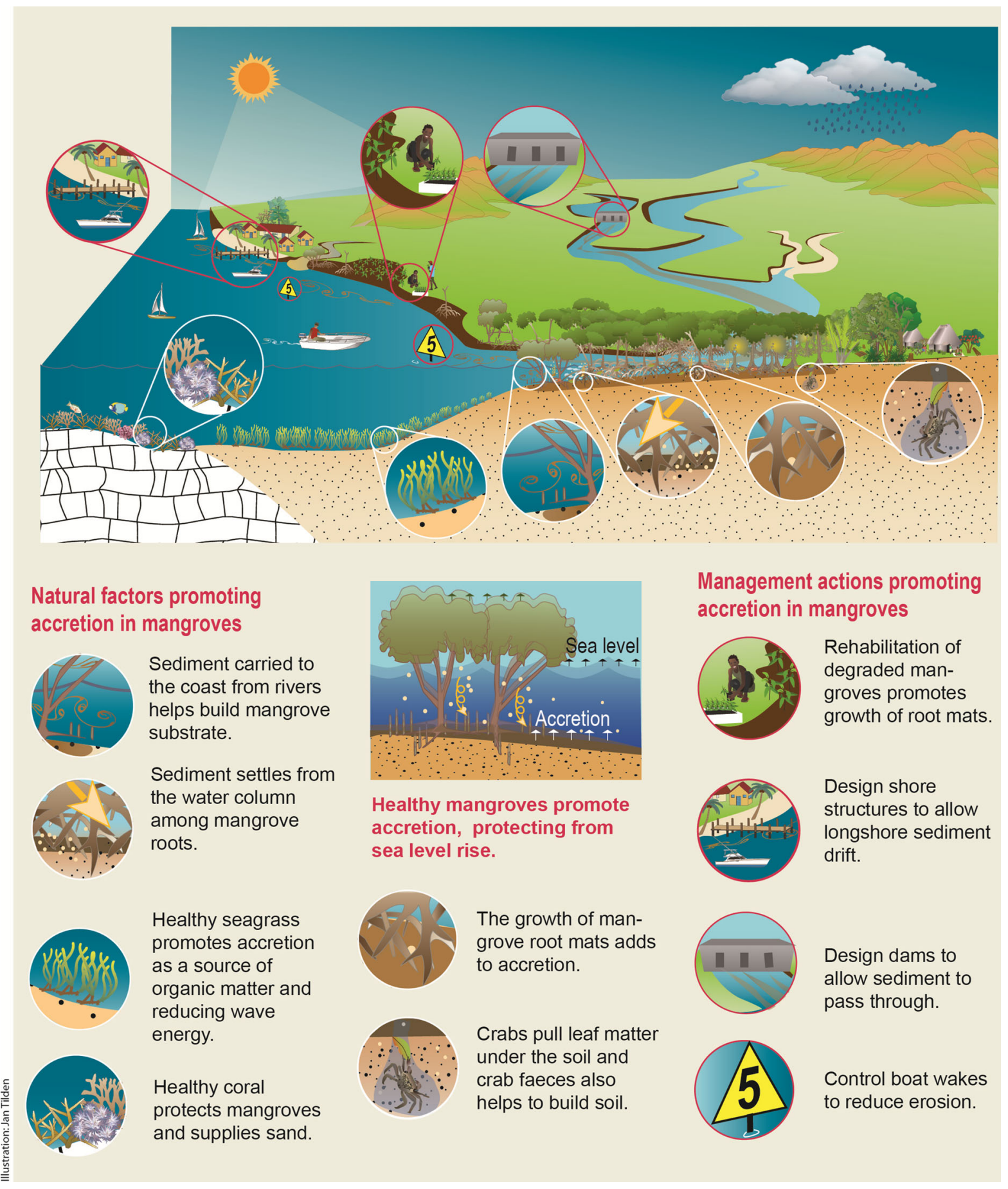

Fig. 6 Management strategies to promote vertical accretion in mangroves

Cooper and McLaughlin (1998), the following specific points are recommended for mangrove vulnerability assessments:
1. The objectives of the assessment should be clear to all, being quantitative assessment of components of vulnerability to assist management 
decisions regarding climate change adaptation planning.

2. The study area should be a landscape/seascape unit such as a watershed, rather than a country. The scale should be such that exposure factors are uniform within the study area.

3. The approach should be interdisciplinary to encompass the human-biophysical environment system rather than human or environmental systems in isolation.

4. The global change drivers included should be recognized as multiple and interacting with socioeconomic development and land-use changes.

5. The approach should be participatory, including stakeholders to include their perspectives, and knowledge; involve local communities living in and adjacent to the mangrove area, and engage both groups in management planning.

6. The assessment should be both historical and future looking. Past site biophysical and social records show resilience or changeability that both assist in understanding vulnerability.

7. Vulnerability assessments should allow for differential adaptive capacity. Management options may be constrained by inadequate resources or information or political-institutional barriers.

\section{Conclusions}

Most ecosystem based vulnerability assessments for climate change impacts have focussed on climate warming and $\mathrm{CO}_{2}$ direct effects (Sutherst et al. 2007; Zhao et al. 2007; Nitschke and Innes 2008; Glick and Stein 2010). Applications of the vulnerability scoping diagram (Polsky et al. 2007; Moreno and Becken 2009; Nicholas and Durham 2012) have allowed comparable approaches to vulnerability assessment, and before this study there has been no previous application of this approach to mangroves or other wetlands. These previous applications have also focussed on climate change rather than associated sea level rise, and this study differs in that it largely focusses on sea level rise vulnerability components. The potential impacts of sea level rise on mangroves as part of climate change impacts is a subject that has received a wealth of research and review over the last 20 years (Table 1). Coastal vulnerability related to sea level rise risks has also received a wealth of research over the same period (Gornitz 1991; Gornitz et al. 1993; Freitas et al. 2006; Diez et al. 2007; Hegde and Reju 2007; Rao et al. 2008; Dwarakish et al. 2009; Abuodha and Woodroffe 2010; Pendleton et al. 2010; Ozyurt and Ergin 2010; Yin et al. 2012; Frihy and ElSayed 2013). Developing from both areas of research, this study has contributed a generalizable methodology by which different mangrove systems may be assessed for vulnerability to climate change impacts, in order to clearly identify management priorities in what is usually a limited budget situation for mangrove management.

The approaches of this ranking system for vulnerability assessment of mangrove systems are multidisciplinary, integrating biotic and abiotic factors along with human management components. They include accurate and validated methods that have previously been developed for other research questions, such as for determining the health of mangrove forests, coral reefs and seagrass as well as spatial analysis of coastal changes, topographic survey and palaeoecological reconstruction of past sea levels. Such multidisciplinary approaches are necessary to giving human communities and decision-makers ways to assess ecological integrity of ecosystems under stress (Borja et al. 2008), and use of standard techniques allows the incorporation of pre-existing data. Forest assessment methods if monitored will provide warning systems for changes in environmental conditions, a stress test providing information for adaptation pathways (Swart et al. 2013) to keep the mangrove system within the bounds of tolerable risk.

If a tested component has resulted in a low vulnerability rank, such as good mangrove condition, positive tree growth, or no seaward edge retreat, while this resilience is an encouraging result, ongoing monitoring is necessary to detect any change in condition. The ability to monitor and anticipate vulnerability is a benefit for potentially affected places and systems (Stern et al. 2013), particularly mangroves which are known to have climate change vulnerability. Vulnerability assessment is not therefore a one-off assessment, within the context of a discrete study, rather, it is a starting point that provides important, yet provisional, indications of climate change vulnerability and resilience. The results obtained effectively form a baseline against which to establish long-term ongoing monitoring, to continue to assess the complex dynamics of climate change 
impacts, and make the best strategic management decisions as these occur.

Acknowledgments This research was funded by the UNEP GEF project "Coastal Resilience to Climate Change: Developing a Generalizable Method for Assessing Vulnerability and Adaptation of Mangroves and Associated Ecosystems" awarded to the World Wildlife Fund (WWF), during which the author was Chief Scientist. The study was facilitated by the program leaders of WWF: Jonathan Cook (Global Coordinator, WWF US), Monifa Fiu (WWF South Pacific), Jason Rubens (WWF Tanzania) and Bertin Tchikangwa (WWF Central Africa). Four anonymous reviewers provided comments that allowed improvements to the manuscript.

Funding This research was funded by a UNEP GEF Medium Sized Grant "Coastal Resilience to Climate Change: Developing a Generalizable Method for Assessing Vulnerability and Adaptation of Mangroves and Associated Ecosystems" awarded to the World Wildlife Fund (WWF US). It was also supported by WWF US through engagement of the author as Chief Scientist 2008-2012.

Open Access This article is distributed under the terms of the Creative Commons Attribution License which permits any use, distribution, and reproduction in any medium, provided the original author(s) and the source are credited.

\section{References}

Abuodha PAO, Woodroffe CD (2010) Assessing vulnerability to sea-level rise using a coastal sensitivity index: a case study from southeast Australia. J Coast Conserv 14:189-205. doi:10.1007/s11852-010-0097-0

Adger WN (2006) Vulnerability. Glob Environ Change 16:268-281

Adger WN, Agrawala S, Mirza MMQ et al (2007) Assessment of adaptation practices, options, constraints and capacity. In: Parry ML, Canziani OF, Palutikof JP et al (eds) Climate change 2007: impacts. Adaptation and Vulnerability. Contribution of Working Group II to the Fourth Assessment Report of the Intergovernmental Panel on Climate Change. Cambridge University Press, Cambridge, pp 717-743

Ajonina GN (2008) Inventory and modeling forest stand dynamics following different levels of wood exploitation pressures in the Douala-Edea Atlantic coast of Cameroon, Central Africa. Dissertation, University of Freiburg

Ajonina G, Chuyong G (2011) Vulnerability assessment of mangrove forest stands from anthropogenic wood exploitation pressures and sea level rise impacts following a recensus survey and analysis of eight year old permanent sample plots in the Douala-Edea Estuary, Cameroon. WWF Central Africa Regional Programme Office, Yaounde

Ajonina G, Tchikangwa B, Chuyong G, Tchamba M (2009) The challenges and prospects of developing a community based generalizable method to assess mangrove ecosystems vulnerability and adaptation to climate change impacts: experience from Cameroon. Nat Faune 24:16-25

Ajonina GN, Kairo J, Grimsditch G, Sembres T, Chuyong G, Diyouke E (2014) Assessment of mangrove carbon stocks in Cameroon, Gabon, the Republic of Congo (RoC) and the Democratic Republic of Congo (DRC) including their potential for reducing emissions from deforestation and forest degradation (REDD+). In: Diop S et al (eds) The land/ocean interactions in the coastal zone of West and Central Africa. Springer, Dordrecht, pp 177-199

Al-Jeneid S, Bahnassy M, Nasr S, El Raey M (2008) Vulnerability assessment and adaptation to the impacts of sea level rise on the Kingdom of Bahrain. Mitig Adapt Strateg Glob Change 13:87-104. doi:10.1007/s11027-007-9083-8

Alongi DM (2008) Mangrove forests: resilience, protection from tsunamis, and responses to global climate change. Estuar Coast Shelf Sci 76:1-13

Alongi DM (2009) Paradigm shifts in mangrove biology. In: Wolanski E, Cahoon D, Perillo GME (eds) Coastal Wetlands: an ecosystem integrated approach. Elsevier Science, Amsterdam, pp 615-640

Ball MC, Cocharane MJ, Rawson HM (1997) Growth and water use of the mangroves Rhizophora apiculata and R. stylosa in response to salinity and humidity under ambient and elevated concentrations of atmospheric $\mathrm{CO}_{2}$. Plant, Cell Environ 20:1158-1166

Bell JD, Johnson JE, Hobday AJ (eds) (2011) Vulnerability of fisheries and aquaculture in the Pacific to climate change. Secretariat of the Pacific Community, Noumea

Borja A, Bricker SB, Dauer DM et al (2008) Overview of integrative tools and methods in assessing ecological integrity in estuarine and coastal systems worldwide. Mar Pollut Bull 56:1519-1537

Bouillon S (2011) Storage beneath mangroves. Nat Geosci 4:282-283

Burgess ND, Mwakalila S, Munishi P, Pfeifer M, Willcock S, Shirima D, Hamidu S, Bulenga GB, Rubens J, Machano H, Marchant R (2013) REDD herrings or REDD menace: response to Beymer-Farris and Bassett. Global Environ Change 23:1349-1354

Cahoon DR (2006) A review of major storm impacts on coastal wetland elevations. Estuar Coast 29:889-898

Cahoon D, Hensel P, Spencer T, Reed DJ, McKee KL, Saintilan N (2006) Coastal wetland vulnerability to relative sea-level rise: Wetland elevation trends and process controls. In: Verhoeven JTA, Beltman B, Bobbink R, Whigham DF (eds) Wetlands and natural resource management. Springer, Berlin, pp 271-292

Cavalcanti VF, Soares MLG, Estrada ECD, Chaves FO (2009) Evaluating mangrove conservation through the analysis of forest structure data. J Coast Res SI 56:390-394

Cheeseman JM (1994) Depressions of photosynthesis in mangrove canopies. In: Baker NR, Bowyer JR (eds) Photoinhibition of photosynthesis, from molecular mechanisms to the field. Bios Scientific Publishers, Oxford, pp 377-389

Cheeseman JM, Clough BF, Carter DR, Lovelock CE, Eong OJ, Sim RG (1991) The analysis of photosynthetic performance in leaves under field conditions, A case study using Bruguiera mangroves. Photosynth Res 29:11-22 
Cheeseman JM, Herendeen LB, Cheeseman AT, Clough BF (1997) Photosynthesis and photoprotection in mangroves under field conditions. Plant, Cell Environ 20:579-588

Church JA, Clark PU, Cazenave A et al (2013) Sea level change. In: Stocker TF, Qin D, Plattner GK et al (eds) Climate change 2013: the physical science basis. Contribution of Working Group I to the Fifth Assessment Report of the Intergovernmental Panel on Climate Change. Cambridge University Press, Cambridge, pp 1137-1216

Clough BF (1992) Primary productivity and growth of mangrove forests. In: Robertson AI, Alongi DM (eds) Tropical mangrove ecosystems. American Geophysical Union, Washington DC, pp 225-250

Clough BF, Sim RG (1989) Changes in gas exchange characteristics and water use efficiency of mangroves in response to salinity and vapour pressure deficit. Oecologia 79:38-44

Cooper JAG, McLaughlin S (1998) Contemporary multidisciplinary approaches to coastal classification and environmental risk analysis. J Coast Res 14:512-524

Dale VH, Joyce LA, McNulty S et al (2001) Climate change and forest disturbances. BioScience 51:723-734

Diez PG, Perillo GME, Piccolo MC (2007) Vulnerability to sealevel rise on the coast of the Buenos Aires Province. J Coast Res 23:119-126

Diop S (2003) Vulnerability assessment of mangroves to environmental change. Estuar Coast Shelf Sci 58:1-2

Dixon RK, Smith J, Guill S (2003) Life on the edge: vulnerability and adaptation of African ecosystems to global climate change. Mitig Adapt Strateg Glob Change 8:93-113

Dwarakish GS, Vinay SA, Natesan U, Asano T, Kakinuma T, Venkataramana K, Jagadeesha Pai B, Babita MK (2009) Coastal vulnerability assessment of the future sea level rise in Udupi coastal zone of Karnataka state, west coast of India. Ocean Coast Manage 52:467-478

Ebi KL, Kovats RS, Menne B (2006) An approach for assessing human health vulnerability and public health interventions to adapt to climate change. Environ Health Perspect 114:1930-1934

Ellison JC (1993) Mangrove retreat with rising sea-level, Bermuda. Estuar Coast Shelf Sci 37:75-87

Ellison JC (2005) Holocene palynology and sea-level change in two estuaries in Southern Irian Jaya. Palaeogeogr Palaeoclimatol Palaeoecol 220:291-309

Ellison JC (2009) Geomorphology and sedimentology of mangrove swamps. In: Wolanski E, Cahoon D, Perillo GME (eds) Coastal Wetlands: an ecosystem integrated approach. Elsevier Science, Amsterdam, pp 564-591

Ellison JC (2012) Climate change vulnerability assessment and adaptation planning for mangrove systems. Washington, DC, World Wildlife Fund. http://www.worldwildlife.org/ publications/climate-change-vulnerability-assessmentand-adaptation-planning-for-mangrove-systems. Accessed 16 Dec 2014

Ellison JC (in press) Applications of palynology and pollen analysis as palaeo-techniques in estuarine systems. In: Weckström KG, Saunders K (eds) Palaeoestuaries. Springer, Berlin

Ellison JC (2014a) Vulnerability of mangroves to climate change. In: Ibrahim F-H, Latiff A, Hakeem KR, Ozturk M (eds) Mangrove ecosystem of Asia: Status, challenges and management strategies. Springer, New York, pp 213-232
Ellison JC (2014b) Climate change adaptation: Management options for mangrove areas. In: Ibrahim F-H, Latiff A, Hakeem KR, Ozturk M (eds) Mangrove ecosystem of Asia: Status, challenges and management strategies. Springer, New York, pp 391-414

Ellison JC, Fiu M (2010) Vulnerability of Fiji's mangroves and associated coral reefs to climate change: a review. WWF South Pacific Program, Suva

Ellison JC, Strickland P (2013) Establishing relative sea level trends where a coast lacks a long term tide gauge. Mitig Adapt Strateg Glob Change. doi:10.1007/s11027-0139534-3

Ellison JC, Zouh I (2012) Vulnerability to climate change of mangroves: assessment from Cameroon, Central Africa. Biology 1:617-638. doi:10.3390/biology 1030617

Ellison JC, Jungblut V, Anderson P, Slaven C (2012) Manual for mangrove monitoring in the Pacific Islands Region. SPREP, Apia

English S, Wilkinson C, Baker V (1997) Manual for survey of tropical marine resources, 2nd edn. Townsville, Australian Institute of Marine Science

Erwin KL (2009) Wetlands and global climate change: the role of wetland restoration in a changing world. Wetlands Ecol Manag 17:71-84

Eslami-Andergoli L, Dale PER, Knight PM, McCallum H (2014) Approaching tipping points: a focussed review of indicators and relevance to managing intertidal ecosystems. Wetlands Ecol Manag. doi:10.1007/s11273-014-9352-8

Faraco LFD, Andriguetto-Filho JM, Lana PC (2010) A methodology for assessing the vulnerability of mangroves and fisherfolk to climate change. Pan Am J Aquat Sci 5:205-223

Farnsworth EJ, Ellison AM, Gong WK (1996) Elevated $\mathrm{CO}_{2}$ alters anatomy, physiology, growth, and reproduction of red mangrove (Rhizophora mangle L.). Oecologia 108:599-609

Field CD (1995) Impact of expected climate change on mangroves. In: Wong YS, Tam NFY (eds) Asia-Pacific symposium on mangrove ecosystems. Springer, Netherlands, pp 75-81

Fiu M, Areki F, Rounds I, Ellison J (2010) Assessing vulnerability of coastal mangroves to impacts of climate change: case studies from Fiji. WWF South Pacific Programme, Suva

Freitas MC, Andrade G, Cachado C, Cardoso AC, Monteiro JH, Brito P, Rebelo L (2006) Coastal land-loss associated with sea-level rise assessed by aerial videotape-assisted vulnerability analysis- the case of mainland Portugal. J Coast Res SI 39:1310-1315

Frihy OE, El-Sayed MK (2013) Vulnerability risk assessment and adaptation to climate change induced sea level rise along the Mediterranean coast of Egypt. Mitig Adapt Strateg Glob Change 18:1215-1237

Füssel H-M (2007) Vulnerability: a generally applicable conceptual framework for climate change research. Global Environ Change 17:155-167

Füssel H-M, Klein RJT (2006) Climate change vulnerability assessments: an evolution of conceptual thinking. Clim Change 75:301-329

Gehrke PC, Sheaves MJ, Terry JP, Boseto DT, Ellison JC, Figa BS, Wani J (2011) Vulnerability of freshwater and estuarine fish habitats in the tropical Pacific to climate change. In: Bell 
JD, Johnson JE, Hobday AJ (eds) Vulnerability of fisheries and aquaculture in the Pacific to climate change. Secretariat of the Pacific Community, Noumea, pp 369-431

Gilman E, Ellison JC, Jungblut V et al (2006) Adapting to Pacific Island mangrove responses to sea level rise and climate change. Climate Res 32:161-176

Gilman E, Ellison JC, Coleman R (2007) Assessment of mangrove response to projected relative sea-level rise and recent historical reconstruction of shoreline position, American Samoa. Environ Monit Assess 124:105-130

Gilman E, Ellison JC, Duke NC, Field C, Fortuna S (2008) Threats to mangroves from climate change and adaptation options: a review. Aquat Bot 89:237-250

Giri C, Ochieng E, Tieszen LL, Zhu Z, Singh A, Loveland T, Masek J, Duke N (2011a) Status and distribution of mangrove forests of the world using earth observation satellite data. Glob Ecol Biogeogr 20:154-159

Giri C, Long J, Tieszen L (2011b) Mapping and monitoring Louisiana's mangroves in the aftermath of the 2010 Gulf of Mexico oil spill. J Coast Res 27:1059-1064

Glick P, Stein BA (2010) Scanning the conservation horizon: a guide to climate change vulnerability assessment. National Wildlife Federation, Washington DC

Gornitz V (1991) Global coastal hazards from future sea level rise. Palaeogeogr Palaeoclimatol Palaeoecol 89:379-398. doi:10.1016/0031-0182(91)90173-O

Gornitz VM, Daniels RC, White TW, Birdwell KR (1993) The development of a coastal risk assessment database: vulnerability to sea level rise in the US Southeast. J Coast Res SI 12:327-338

Gravelle G, Mimura N (2008) Vulnerability assessment of sealevel rise in Viti Levu, Fiji Islands. Sustain Sci 3:171-180

Hahn MB, Riederer AM, Foster SO (2009) The livelihood vulnerability index: a pragmatic approach to assessing risks from climate change variability and change- A case study in Mozambique. Glob Envir Change 19:74-88

Hansen J, Hoffman J, Drews C, Mielbrecht E (2010) Designing climate smart conservation: guidance and case studies. Conserv Biol 24:63-69

Hegde AV, Reju VR (2007) Development of a costal vulnerability index for Mangalore coast India. J Coast Res 23:106-111

Heileman S, Cabanban AS (2013) Terminal evaluation of the UNEP GEF medium sized project: Coastal resilience to climate change: Developing a generalizable method for assessing vulnerability and adaptation of mangroves and associated ecosystems. United Nations Environment Programme, Nairobi

Intergovernmental Panel on Climate Change (IPCC) (2007) Climate change 2007: Synthesis report. Contribution of Working Groups I, II, and III to the Fourth Assessment Report of the Intergovernmental Panel on Climate Change. Intergovernmental Panel on Climate Change, Geneva

Intergovernmental Panel on Climate Change (IPCC) (2014) In: Barros VR, Field CB, Dokken DJ et al (eds) Climate change 2014: impacts, adaptation, and vulnerability. Part B: Regional Aspects. Contribution of Working Group II to the Fifth Assessment Report of the Intergovernmental Panel on Climate Change. Cambridge University Press, Cambridge
Jallow BP, Toure S, Barrow MMK, Mathieu AA (1999) Coastal zone of The Gambia and the Abidjan region in Côte d'Ivoire: sea level rise vulnerability, response strategies, and adaptation options. Climate Res 12:129-136

Johnson JE, Marshall PA (eds) (2007) Climate change and the great barrier reef: a vulnerability assessment. Great Barrier Reef Marine Park Authority and Australian Greenhouse Office, Townsville

Kauffman JB, Heider C, Cole TG, Dwire KA, Donato DC (2011) Ecosystem carbon stocks of Micronesian mangrove forests. Wetlands 31:343-352

Kelly PM, Adger WN (2000) Theory and practice in assessing vulnerability to climate change and facilitating adaptation. Clim Change 47:325-352

Kimeu B, Machano H (2011) Elevation survey report for the above tide area in North Rufiji Delta. WWF Tanzania Country Office, Dar es Salaam

Komiyama A, Ong JE, Poungparn S (2008) Allometry, biomass and productivity of mangrove forests: a review. Aquat Bot 89:128-137

Krauss KW, Allen JA, Cahoon DR (2003) Differential rates of vertical accretion and elevation change among aerial root types in Micronesian mangrove forests. Estuar Coast Shelf Sci 56:251-259

Krauss KW, Cahoon DR, Allen JA, Ewel KC, Lynch JC, Cormier N (2010) Surface elevation change and susceptibility of different mangrove zones to sea-level rise on Pacific high islands of Micronesia. Ecosystems 13:129-143

Ksiksi TS, Youssef T, Abdelmawla E (2012) Sea level rise and Abu Dhabi coastlines: an initial assessment of the impact on land and mangrove areas. J Ecosyst Ecogr 2:115. doi:10. 4172/2157-7625.1000115

Langley JA, McKee KL, Cahoon DR, Cherry JA, Megonigala JP (2009) Elevated $\mathrm{CO}_{2}$ stimulates marsh elevation gain, counterbalancing sea-level rise. Proc Natl Acad Sci 106:6182-6186

Lenton TM, Held H, Kriegler E, Hall JW, Lucht W, Rahmstorf S, Schellnhuber HJ (2008) Tipping elements in the Earth's climate system. Proc Natl Acad Sci 105: 1786-1793

Li S, Meng X, Ge Z, Zhang L (2014) Vulnerability assessment of the coastal mangrove ecosystems in Guangxi, China, to sea-level rise. Reg Environ Change. doi:10.1007/s10113014-0639-3

Lovelock CE, Ellison JC (2007) Vulnerability of mangroves and tidal wetlands of the Great Barrier Reef to climate change. In: Johnson JE, Marshall PA (eds) Climate change and the Great Barrier Reef: A vulnerability assessment. Great Barrier Reef Marine Park Authority and Australian Greenhouse Office, Townsville, pp 237-269

Lugo AE, Snedaker SC (1974) The ecology of mangroves. Ann Rev Ecol Syst 5:39-64

McKee KL (2011) Biophysical controls on accretion and elevation change in Caribbean mangrove ecosystems. Estuar Coast Shelf Sci 9:475-483

McKee KL, Cahoon DR, Feller IC (2007) Caribbean mangroves adjust to rising sea levels through biotic controls on change in soil elevation. Glob Ecol Biogeogr 16:545-556

McLeod E, Salm RV (2006) Managing mangroves for resilience to climate change. IUCN, Gland 
Mcleod E, Hinkel J, Vafeidis AT, Nicholls RJ, Harvey N, Salm $\mathrm{R}$ (2010) Sea-level rise vulnerability in the countries of the coral triangle. Sustain Sci 5:207-222

Meehl GA, Stocker TF, Collins W et al (2007) Global climate projections. In: Solomon S, Qin W, Manning M et al (eds) Climate change 2007: the physical science basis. Contribution of Working Group I to the Fourth Assessment Report of the Intergovernmental Panel on Climate Change. Cambridge University Press, Cambridge, pp 747-846

Mertz O, Halsnæs K, Olesen JE, Rasmussen K (2009) Adaptation to climate change in developing countries. Environ Manag 43:743-752

Moreno A, Becken S (2009) A climate change vulnerability assessment methodology for coastal tourism. J Sustainable Tour 17:473-488

Mumby PJ, Edwards AJ, Arias-González JE, Lindeman KC, Blackwell PG, Gall A, Gorczynska MI, Harborne AR, Pescod CL, Renken H, Wabnitz CCC, Llewellyn G (2004) Mangroves enhance the biomass of coral reef fish communities in the Caribbean. Nature 427:533-536

Nicholas KA, Durham DH (2012) Farm-scale adaptation and vulnerability to environmental stresses: insights from winegrowing in Northern California. Global Environ Ch 22:483-494

Nitschke CR, Innes JL (2008) Integrating climate change into forest management in South-Central British Columbia: an assessment of landscape vulnerability and development of a climate-smart framework. Forest Ecol Manag 256: 313-327

Ntyam SCO, Armah AK, Ajonina GN, George W, Adomako JK, Elvis N, Obiang BO (2014) Importance of mangrove litter production in the protection of Atlantic coastal forest of Cameroon and Ghana. In: Diop S et al (eds) The Land/ Ocean Interactions in the Coastal Zone of West and Central Africa. Springer, Dordrecht, pp 123-137

Obura D (2010) Vulnerability and resilience to climate change of coral reefs of Mafia and Songosongo Islands Tanzania. Turbidity and fisheries as driving forces. WWF Tanzania Country Office, Mombasa

Oppenheimer M, Campos M, Warren R et al (2014) Emergent risks and key vulnerabilities. In: Field CB, Barros VR, Dokken DJ et al (eds) Climate Change 2014: Impacts, Adaptation, and Vulnerability. Part A: Global and Sectoral Aspects. Contribution of Working Group II to the Fifth Assessment Report of the Intergovernmental Panel on Climate Change. Cambridge University Press, Cambridge, pp 1039-1099

Ozyurt G, Ergin A (2010) Improving coastal vulnerability assessments to sea-level rise: a new indicator based methodology for decision makers. J Coast Res 26:265-273

Pellegrini JAC, Soares MLG, Chaves FO, Estrada GCD, Cavalcanti VF (2009) A method for the classification of mangrove forests and sensitivity/vulnerability analysis. J Coast Res SI 56:443-447

Pendleton EA, Thieler ER, Williams SJ (2010) Importance of coastal change variables in determining vulnerability to sea- and lake-level change. J Coast Res 26:176-183

Permanent Service for Mean Sea Level (PSMSL) (2014) Obtaining tide gauge data. National Oceanography Centre, Liverpool. http://www.psmsl.org/data/obtaining/ Accessed 6 October 2014
Polsky C, Neff R, Yarnal B (2007) Building comparable global change vulnerability assessments: the vulnerability scoping diagram. Global Environ Change 17:472-485

Pugh DT (1987) Tides, surges and mean sea-level. Wiley, Chichester

Punwong P, Marchant R, Selby K (2013) Holocene mangrove dynamics and environmental change in the Rufiji Delta, Tanzania. Veg Hist Archaeobot. doi:10.1007/s00334-0120383-x

Rao KN, Subraelu P, Rao TV, Malini BH, Ratheesh R, Bhattacharya S, Rajawat AS (2008) Sea-level rise and coastal vulnerability: an assessment of Andhra Pradesh coast, India through remote sensing and GIS. J Coast Conserv 12:195-207. doi:10.1007/s11852-009-0042-2

Remling E, Persson A (2014) Who is adaptation for? Vulnerability and adaptation benefits in proposals approved by the UNFCCC Adaptation Fund. Clim Dev. doi:10.1080/ 17565529.2014.886992

Rogers K, Saintilan N, Heijnis H (2005a) Mangrove encroachment of salt marsh in Western Port Bay, Victoria, the role of sedimentation, subsidence, and sea level rise. Estuaries 28:551-559

Rogers K, Saintilan N, Cahoon DR (2005b) Surface elevation dynamics in a regenerating mangrove forest at Homebush Bay, Australia. Wetlands Ecol Manag 13:587-598

Rybczyk JM, Callaway JC (2009) Surface elevation models. In: Wolanski E, Cahoon D, Perillo GME (eds) Coastal Wetlands: an ecosystem integrated approach. Elsevier Science, Amsterdam, pp 835-854

Saenger P, Snedaker SC (1993) Pan tropical trends in mangrove above-ground biomass and annual litter fall. Oecologia 96:293-299

Schröter D, Polsky C, Pitt AG (2005) Assessing vulnerabilities to the effect of global climate change: an eight-step approach. Mitig Adapt Strateg Glob Change 10:573-596

Semeniuk V (1994) Predicting the effect of sea-level rise on mangroves in northwestern Australia. J Coast Res 10:1050-1076

Shearman PL (2010) Recent change in the extent of mangroves in the northern Gulf of Papua, Papua New Guinea. Ambio 39:181-189

Smit B, Wandel J (2006) Adaptation, adaptive capacity and vulnerability. Global Environ Change 16:282-292

Smith TJ III, Duke NC (1987) Physical determinants of interestuary variation in mangrove species richness around the tropical coastline of Australia. J Biogeogr 14:9-19

Snedaker SC (1995) Mangroves and climate change in the Florida and Caribbean region: scenarios and hypotheses. Hydrobiology 295:43-49

Soares MLG (2009) A conceptual model for the responses of mangrove forests to sea level rise. J Coast Res 56:267-271

Spalding M, Kainuma M, Collins L (2010) World Atlas of Mangroves. Earthscan, Washington DC

Stern PC, Ebi KL, Leichenko R, Olson RS, Steinbruner JD, Lempert R (2013) Managing risk with climate vulnerability science. Nat Clim Change 3:607-609

Stigter TY, Ribeiro L, Dill AMMC (2006) Evaluation of an intrinsic and a specific vulnerability assessment method in comparison with groundwater salinisation and nitrate contamination levels in two agricultural regions in the south of Portugal. Hydrogeol J 14:79-99 
Sutherst RW, Maywald GF, Burne AS (2007) Including species interactions in risk assessments for global change. Glob Change Biol 13:1843-1859

Swart R, Fuss S, Obersteiner M, Ruti P, Teichmann C, Vautard R (2013) Beyond vulnerability assessment. Nat Clim Change 3:942-943

Syvitski JPM, Kettner AJ, Overeem I, Hutton EWH, Hannon MT, Brakenridge GR, Day J, Vorosmarty C, Saito Y, Giosan L, Nicholls RJ (2009) Sinking deltas due to human activities. Nat Geosci 2(10):681-687

Taylor A (2011) Tanzania Study-Ecosystems, Development, and Climate Adaptation: Improving the knowledge base for policies, planning and management. Stockholm Environment Institute, Oxford. http://www.sei-international. org/publications?pid=2177. Accessed 28 Aug 2014

Thom BG (1984) Mangrove ecology- A geomorphological perspective. In: Clough BF (ed) Mangrove ecosystems in Australia: structure function and management. Australian Institute of Marine Science, Townsville, pp 3-18

Tran Thi V, Tien Thi Xuan A, Phan Nguyen H, Dahdouh-Guebas F, Koedam N (2014) Application of remote sensing and GIS for detection of long-term mangrove shoreline changes in Mui Ca Mau, Vietnam. Biogeosciences 11:3781-3795

Turner BL, Kasperson RE, Matson PA, McCarthy JJ, Corell RW, Christensen L, Ecklet N, Kasperson JX, Luers A, Martello ML, Polsky C, Pulipher A, Schiller A (2003) A framework for vulnerability analysis in sustainability science. Proc Natl Acad Sci 100:8074-8079

Wagner GM, Sallema-Mtui R (2010) Change analysis of RufijiMafia-Kilwa Mangroves (Tanzania) in relation to climate change factors and anthropogenic pressures. WWF Tanzania Country Office, Dar es Salaam
Wang C, Yarnal B (2012) The vulnerability of the elderly to hurricane hazards in Sarasota, Florida. Nat Hazards 63:349-373

Wang Y, Bonynge G, Nugranad J, Traber M, Ngusaru A, Tobey J, Hale L, Bowen R, Makota V (2003) Remote sensing of mangrove change along the Tanzania coast. Mar Geod 26:35-48

Waycott M, McKenzie LJ, Mellors JE, Ellison JC, Sheaves MT, Collier C, Schwarz AM, Webb A, Johnson JE, Payri CE (2011) Vulnerability of mangroves, sea grasses and intertidal flats in the tropical Pacific to climate change. In: Bell JD, Johnson JE, Hobday AJ (eds) Vulnerability of fisheries and aquaculture in the Pacific to climate change. Secretariat of the Pacific Community, Noumea, pp 297-368

Whelan KRT, Smith TJ III, Cahoon DR, Lynch JC, Anderson GH (2005) Groundwater control of mangrove surface elevation, shrink and swell varies with soil depth. Estuaries 28:833-843

Wong PP, Losada IJ, Gattuso J-P et al (2014) Coastal systems and low-lying areas. In: Field CB, Barros VR, Dokken DJ et al (eds) Climate Change 2014: Impacts, Adaptation, and Vulnerability. Part A: Global and Sectoral Aspects. Contribution of Working Group II to the Fifth Assessment Report of the Intergovernmental Panel on Climate Change. Cambridge University Press, Cambridge, pp 361-409

Yin J, Yin Z, Wang J, Xu S (2012) National assessment of coastal vulnerability to sea-level rise for the Chinese coast. J Coast Conserv 16:123-133

Zhao HX, Wu SH, Jiang LG (2007) Research advances in vulnerability assessment of natural ecosystem response to climate change. Chin J Appl Ecol 18:445-450 